\title{
Article \\ A Co-Culture Model of the Human Respiratory Tract to Discriminate the Toxicological Profile of Cationic Nanoparticles According to Their Surface Charge Density
}

\author{
Yasmin Arezki, Juliette Cornacchia, Mickaël Rapp, Luc Lebeau (D), Françoise Pons and Carole Ronzani *
}

check for

updates

Citation: Arezki, Y.; Cornacchia, J.;

Rapp, M.; Lebeau, L.; Pons, F.;

Ronzani, C. A Co-Culture Model of

the Human Respiratory Tract to

Discriminate the Toxicological Profile of Cationic Nanoparticles According to Their Surface Charge Density.

Toxics 2021, 9, 210. https://doi.org/ $10.3390 /$ toxics 9090210

Academic Editor: Susana I. L. Gomes

Received: 23 June 2021

Accepted: 28 August 2021

Published: 31 August 2021

Publisher's Note: MDPI stays neutral with regard to jurisdictional claims in published maps and institutional affiliations.

Copyright: (C) 2021 by the authors Licensee MDPI, Basel, Switzerland. This article is an open access article distributed under the terms and conditions of the Creative Commons Attribution (CC BY) license (https:/ / creativecommons.org/licenses/by/ $4.0 /)$.
Laboratoire de Conception et Application de Molécules Bioactives, Faculté de Pharmacie, UMR 7199, CNRS-Université de Strasbourg, 67400 Illkirch, France; y.arezki@unistra.fr (Y.A.); jcornacchia@unistra.fr (J.C.); rappm@unistra.fr (M.R.); llebeau@unistra.fr (L.L.); pons@unistra.fr (F.P.)

* Correspondence: ronzani@unistra.fr

Abstract: This study aimed at discriminating with sensitivity the toxicological effects of carbon dots (CDs) with various zeta potential $(\zeta)$ and charge density $\left(Q_{e k}\right)$ in different cellular models of the human respiratory tract. One anionic and three cationic $\mathrm{CDs}$ were synthetized as follows: $\mathrm{CD}-\mathrm{COOH}$ $(\zeta=-43.3 \mathrm{mV})$; CD-PEI600 $\left(\mathrm{Q}_{\mathrm{ek}}=4.70 \mu \mathrm{mol} / \mathrm{mg} ; \zeta=+31.8 \mathrm{mV}\right)$; CD-PEHA $\left(\mathrm{Q}_{\mathrm{ek}}=3.30 \mu \mathrm{mol} / \mathrm{mg}\right.$; $\zeta=+29.2 \mathrm{mV})$ and CD-DMEDA $\left(\mathrm{Q}_{\mathrm{ek}}=0.01 \mu \mathrm{mol} / \mathrm{mg} ; \zeta=+11.1 \mathrm{mV}\right)$. Epithelial cells (A549) and macrophages (THP-1) were seeded alone or as co-cultures with different A549:THP-1 ratios. The obtained models were characterized, and multiple biological responses evoked by CDs were assessed in the mono-cultures and the best co-culture model. With 14\% macrophages, the 2:1 ratio co-culture best mimicked the in vivo conditions and responded to lipopolysaccharides. The anionic CD did not induce any effect in the mono-cultures nor in the co-culture. Among the cationic CDs, the one with the highest charge density (CD-PEI600) induced the most pronounced responses whatever the culture model. The cationic CDs of low charge density (CD-PEHA and CD-DMEDA) evoked similar responses in the mono-cultures, whereas in the co-culture, the three cationic CDs ranked according to their charge density (CD-PEI600 > CD-PEHA > CD-DMEDA), when taking into account their inflammatory effect. Thus, the co-culture system developed in this study appears to be a sensitive model for finely discriminating the toxicological profile of cationic nanoparticles differing by the density of their surface charges.

Keywords: co-culture model; multi-endpoint approach; nanoparticles; carbon dots; nanotoxicology; lung toxicity; inflammatory potential

\section{Introduction}

The production of manufactured nanoparticles (NPs) raises genuine concerns about health risks, especially by inhalation $[1,2]$. In vivo studies have provided valuable information on NP deposition and toxicological effects in the lung [3,4]. Inhaled NPs were shown to deposit all throughout the airways, and to particularly accumulate in the alveoli [4], where they are internalized by epithelial cells and macrophages [5]. Furthermore, lung tissue inflammation and remodeling were reported in rodents upon inhalation or lung instillation of NPs [5-7]. However, the huge diversity of NPs in terms of physicochemical characteristics, including chemical composition, size, shape, and surface charge means that not all NPs can be evaluated by in vivo approaches [8]. Indeed, animal studies are costly, time-consuming and should be reduced in accordance with the $3 \mathrm{R}$ principle. Moreover, cellular and molecular mechanisms involved in NP toxicity cannot be easily studied in vivo [9]. Therefore, over the last years, several in vitro models have been developed to investigate on the safety of NPs $[10,11]$.

Both mono- and co-culture models are currently used to assess the toxicological effects of NPs in the lung. Mono-culture systems are mainly based on bronchial (Calu-3, 
NCI-H292 or 16-HBE) or alveolar (A549) epithelial cell lines and/or on immune cells, particularly macrophages (especially activated THP-1), as they are the main cell targets for inhaled NPs [12]. These mono-culture systems are commonly used to screen a large number of NPs [13] and to determine their toxicity mechanisms [14]. They are also used to propose toxicological endpoints to be considered for NP safety assessment, e.g., NP uptake, NP intracellular localization, cell death mechanisms, oxidative stress, pro-inflammatory reactions, immunotoxicity or genotoxicity $[10,15]$. Nevertheless, criticisms have emerged regarding these mono-culture models, in that they are found to be too far from reality to allow proper evaluation of the complex interactions of NPs with the respiratory system [16]. Co-culture models have therefore been developed in order to better predict the toxicological effects of NPs in vivo. By associating various cell types such as epithelial, endothelial, macrophage, or dendritic cells, these co-culture models aim at closely mimicking cell-cell communications and cell-particle interactions occurring in the lung $[9,17,18]$. Unfortunately, some limitations have so far hampered the impact of co-culture models in NP safety assessment. First, such systems may be difficult to apply in screening or high-throughput assays due to more complex implementation and lower reproducibility as compared to standard monoculture models. Second, only few studies have currently compared the effects of NPs in a co-culture model versus the corresponding mono-culture models, in order to demonstrate the real added value of using such more sophisticated models [9,19-21]. Thirdly, due to technical constraints, most of the investigations carried out on co-cultures are descriptive cytotoxicity studies, without questioning the mechanisms involved in the NP-induced responses [9,10].

In this context, the first objective of the work reported herein was to establish and characterize a simple and robust co-culture model that mimics the deep lung. To do so, alveolar epithelial cells (A549 cell line) and macrophages (activated-THP-1 cell line) were selected. Although these cell lines are not normal which could be a limitation, they are widely used as in vitro airway models [21-26]. To set up an optimal model, A549 and THP-1 cells were seeded at several A549:THP-1 ratios, and the different established coculture systems were characterized by determining their effective macrophage/epithelial cell ratio at the time of their use, and their capacity to respond to lipopolysaccharides (LPS), a well-known pro-inflammatory stimulus. After selecting the best co-culture model, our second objective was to determine the added value of this model in comparison with the respective mono-cultures for NP toxicity testing. To do so, we used carbon-based NPs called carbon dots (CDs), displaying easily tunable surface charge properties, and multiple biological endpoints, including NP cell uptake, oxidative stress, inflammation, and cell viability and death. CDs were discovered just over a decade ago [27] and are nanomaterials of tremendous interest to the scientific and industrial communities due to their unique and exciting properties, including ease of synthesis and functionalization, very small size (few nanometers), water solubility, intrinsic fluorescence and resistance to photobleaching [28]. Beside their applications in various fields of highly innovative and competitive industrial technologies, such as optoelectronics, photovoltaics and energy storage, chemical catalysis and chemical sensors, and anti-counterfeiting, CDs are currently being developed in nanomedicine for drug or gene delivery, biomedical imaging and theranostic applications [29-32]. Although they are generally described as biocompatible [33], a complete evaluation of their safety, however, is necessary mainly because of the large diversity of the synthesis methods that have been developed, leading to NPs with extremely variable physicochemical characteristics. Indeed, physicochemical characteristics of NPs, such as size, shape, chemical composition, or surface chemistry, are well known to impact their toxicological effects in the lung [34,35]. Among these characteristics, the surface charge is one of the most prominent factors of NP toxicity, with cationic NPs generally exhibiting greater toxicity than negative ones [36,37]. However, our group recently demonstrated that a cationic charge does not systematically confer toxicity to NPs [38]. In an original way, we have highlighted that the surface charge density of a cationic NP is more predictive of its toxicity than the absolute value of its zeta potential (ל) [39]. Thus, in the present 
work, in order to reinforce these new data concerning the role of surface charge density in the toxicity of cationic NPs, we exposed our mono- and co-culture models to three cationic CDs exhibiting an increasing quantity of amino groups at their periphery, i.e., increasing surface charge density. These NPs were produced from citric acid in the presence of various amine group-containing passivation reagents, namely low-molecular-weight branched poly(ethylenimine) (MW = $600 \mathrm{Da}, \mathrm{bPEI} 600)$, pentaethylene hexamine (PEHA), and $\mathrm{N}, \mathrm{N}$-dimethylethylene diamine (DMEDA). A negatively charged CD was also produced, through pyrolysis of ammonium citrate alone, and used as a control throughout our study. Our hypothesis was that the developed co-culture model of the human respiratory tract composed of epithelial cells and macrophages would allow to a more precise determination of the toxicological effects of NPs differing by their surface charge density than the respective mono-culture models.

\section{Materials and Methods}

\subsection{Synthesis of $C D$ s}

The CDs investigated herein were produced according to the following procedures. Their surface charge density was tuned by synthetizing the NPs with passivation reagent containing an increasing number of amino groups (bPEI600 > DMEDA > PEHA).

CD-PEI600 and CD-PEHA. Citric acid (2.00 g), bPEI600 (8.00 g), and $\mathrm{H}_{2} \mathrm{O}(50 \mathrm{~mL})$ were mixed in a beaker, and heated at $250{ }^{\circ} \mathrm{C}$ for $4 \mathrm{~h}$, under continuous stirring. Small portions of water $(5 \mathrm{~mL})$ were periodically added to the mixture to prevent immobilization of the magnetic stirring bar. At the end of the process, the residue was dissolved in $\mathrm{HCl}$ $0.1 \mathrm{~N}$, and loaded in a dialysis bag (MWCO $1000 \mathrm{Da}$ ) for dialysis against $\mathrm{HCl} 0.1 \mathrm{~N}(24 \mathrm{~h}$ ) and ultra-pure water $(24 \mathrm{~h})$. The dialysate was filtered through a $0.22-\mu \mathrm{m}$ polyethersulfone (PES) membrane and lyophilized to yield CD-PEI600 as an orange hygroscopic powder $(1.63 \mathrm{~g})$. CD-PEHA (1.41 g) was obtained similarly except that bPEI600 was replaced by PEHA (8.00 g).

CD-DMEDA. Citric acid $(4.00 \mathrm{~g})$, DMEDA $(16.00 \mathrm{~g})$, and water $(10 \mathrm{~mL})$ were mixed to homogeneity, introduced into a Teflon ${ }^{\circledR}$-lined stainless-steel reactor, and heated at $210{ }^{\circ} \mathrm{C}$ for $72 \mathrm{~h}$. The resulting solution was cooled to RT, transferred into a dialysis bag and treated as above to yield CD-DMEDA as a brown hygroscopic powder $(1.11 \mathrm{~g})$.

$\mathrm{CD}-\mathrm{COOH}$. Triammonium citrate $(75.0 \mathrm{~g})$ and $\mathrm{KH}_{2} \mathrm{PO}_{4}(15.0 \mathrm{~g})$ in pure water $(150 \mathrm{~mL})$ were mixed in a beaker and heated at $250{ }^{\circ} \mathrm{C}$ for $1 \mathrm{~h}$, under continuous stirring. The resulting dark residue was dissolved in $\mathrm{HCl} 0.1 \mathrm{~N}$, filtered through a $0.45-\mu \mathrm{m}$ PES membrane, and dialyzed. The dialysate was filtered through a $0.22-\mu \mathrm{m}$ PES membrane and lyophilized to yield $\mathrm{CD}-\mathrm{COOH}$ as a dark-brown powdered material $(0.89 \mathrm{~g})$.

\subsection{Characterization of $\mathrm{CDs}$}

The hydrodynamic diameter of CDs was measured by dynamic light scattering (DLS, Zetasizer Nano ZS, Malvern Instruments, Paris, France) and calculated from the number distribution graph. Zeta potential was measured by DLS as well and calculated with the Smoluchowski's equation. All measurements were performed in triplicate on fresh samples $\left(1.0 \mathrm{mg} / \mathrm{mL}\right.$ in $1.5 \mathrm{mM} \mathrm{NaCl} \mathrm{pH} \mathrm{7.4)}$ at $25^{\circ} \mathrm{C}$. The surface charge density of CDs was determined by means of polyelectrolyte titration as described elsewhere [39]. In brief, the electrokinetic charge $\left(\mathrm{Q}_{\mathrm{ek}}\right)$ of the $\mathrm{CDs}$ was determined by monitoring zeta potential variation in the sample $(1.0 \mathrm{mg} / \mathrm{mL}, \mathrm{NaCl} 1.5 \mathrm{mM} \mathrm{pH} 7.4)$ alongside spiking with a solution of poly(acrylic acid) (PAA, MW $\pm 1800 \mathrm{Da}, \mathrm{NaCl} 1.5 \mathrm{mM} \mathrm{pH} \mathrm{7.4).} \mathrm{Q}_{\mathrm{ek}}$ was calculated from the amount of PAA required to bring $\zeta$ down to zero. The data were expressed in $\mu \mathrm{mol}$ of amine per mg of material. Optical properties of the CDs were characterized by carrying out UV-visible and fluorescence measurements on CD samples $(1.0 \mathrm{mg} / \mathrm{mL}$ in $1.5 \mathrm{mM} \mathrm{NaCl} \mathrm{pH}$ 7.4) using a Varioskan multimode reader (Thermo Scientific, IllkirchGraffenstaden, France). 


\subsection{Cell Culture}

The human alveolar epithelial cell line A549 (CCL-185 ${ }^{\mathrm{TM}}$, ATCC) was grown in DMEM/F12 culture medium containing $2 \mathrm{mM}$ L-glutamine, $100 \mathrm{UI} / \mathrm{mL}$ penicillin, $100 \mathrm{\mu g} / \mathrm{mL}$ streptomycin, $5 \mathrm{mM}$ Hepes and $10 \%$ fetal bovine serum (FBS). The human monocytes cell line THP-1 (TIB-202 ${ }^{\mathrm{TM}}$, ATCC) was grown in RPMI-1640 culture medium containing $2 \mathrm{mM} \mathrm{L}$-glutamine, $0.05 \mathrm{mM}$ 2-mercaptoethanol, $100 \mathrm{UI} / \mathrm{mL}$ penicillin, $100 \mu \mathrm{g} / \mathrm{mL}$ streptomycin, and 10\% heat inactivated FBS (all reagents from GIBCO, Thermo Scientific, Illkirch-Graffenstaden, France). The two cell lines were grown in culture flasks at $37^{\circ} \mathrm{C}$ in a $5 \% \mathrm{CO}_{2}$ humidified chamber. For the experiments, the RPMI-1640 was used as culture medium in mono-cultures (A549 and THP-1) and co-cultures, after checking that medium change from DMEM-F12 (culture) to RPMI-1640 (experiment) did not impact the A549 cell growth. Co-cultures based on A549 and THP-1 cells have already been established in RPMI medium in the literature (e.g., Dekali et al. [21]).

\subsection{Mono- and Co-Culture Models}

The culture models developed herein were adapted from previous studies combining A549 and THP-1 cells in co-culture [21-26]. Mono-cultures of activated THP-1 and A549 cells were prepared as follows. THP-1 cells were seeded into 24-well culture plates at a density of 30,000,75,000, 150,000, or 300,000 cells/well in RPMI-1640 culture medium, and were differentiated into macrophages by incubation with $10 \mathrm{ng} / \mathrm{mL}$ phorbol 12-myristate 13-acetate (PMA, Sigma-Aldrich, St. Louis, MO, USA) for $24 \mathrm{~h}$ (Figure 1). Then, the cells were rinsed with phosphate-buffered saline (PBS) to remove PMA and further cultured in RPMI-1640 for $24 \mathrm{~h}$ before LPS or CD exposure. A549 epithelial cells were seeded into 24-well culture plates at a density of 150,000 cells/well in RPMI-1640 culture medium and exposed to LPS or CDs $24 \mathrm{~h}$ later (Figure 1). At this time, A549 cultures were at confluency. The co-cultures of THP-1 and A549 cells were prepared in parallel with monocultures (Figure 1). Briefly, THP-1 cells were seeded into 24-well culture plates at a density of $30,000,75,000,150,000$, or 300,000 cells/well, and were differentiated into macrophages by incubation with $10 \mathrm{ng} / \mathrm{mL}$ PMA for $24 \mathrm{~h}$. Then, the cells were rinsed with PBS to remove PMA, and A549 cells in RPMI-1640 medium were added at a density of 150,000 cells/well to obtain various A549:THP-1 ratios, namely 5:1, 2:1, 1:1, and 1:2. Co-cultures were grown for $24 \mathrm{~h}$ and characterized by flow cytometry or exposed to LPS or CDs as described below. Thus, the number of A549 cell in mono- and co-cultures was fixed and reached confluency whatever the culture model. Only the THP-1 number varied in order to modulate the proportion between the two cell types within the co-culture. The THP-1 number was modulated in the same way in the mono-culture models to allow comparison of the LPSor CD-evoked biological responses between the mono- and co-culture models. Regarding the co-culture organization, the epithelial cells were located at the bottom of the wells and the macrophages often arranged into or on top of the epithelial cell layer.

\subsection{Characterization of the Co-Culture Models by Fluorescence Activated Cell Sorting (FACS)}

Co-cultures were rinsed with PBS, and cells were harvested by $0.05 \%$ trypsin treatment, transferred into microtubes and centrifuged $(5 \mathrm{~min}, 200 \times \mathrm{g}$ ). The pelleted cells were rinsed with PBS containing $0.5 \%$ BSA before staining for 20 min with an APC-Cy7 anti-human CD14 antibody (M5E2 clone, $10 \mu \mathrm{g} / \mathrm{mL}$, BioLegend, CA, USA) to identify THP-1-derived macrophages. After staining, cells were rinsed twice with PBS, cell suspensions were analyzed with a LSRFortessa X $20^{\mathrm{TM}}$ flow cytometer (BD Biosciences, France), and collected data were analyzed using the FlowJo ${ }^{\mathrm{TM}}$ software (v 10.2, Ashland, OR, USA). Macrophages were discriminated from epithelial cells according to their fluorescence intensity collected using an APC-Cy7 (red laser) channel. Macrophage number was expressed as a percentage of total cells inside the co-culture. 


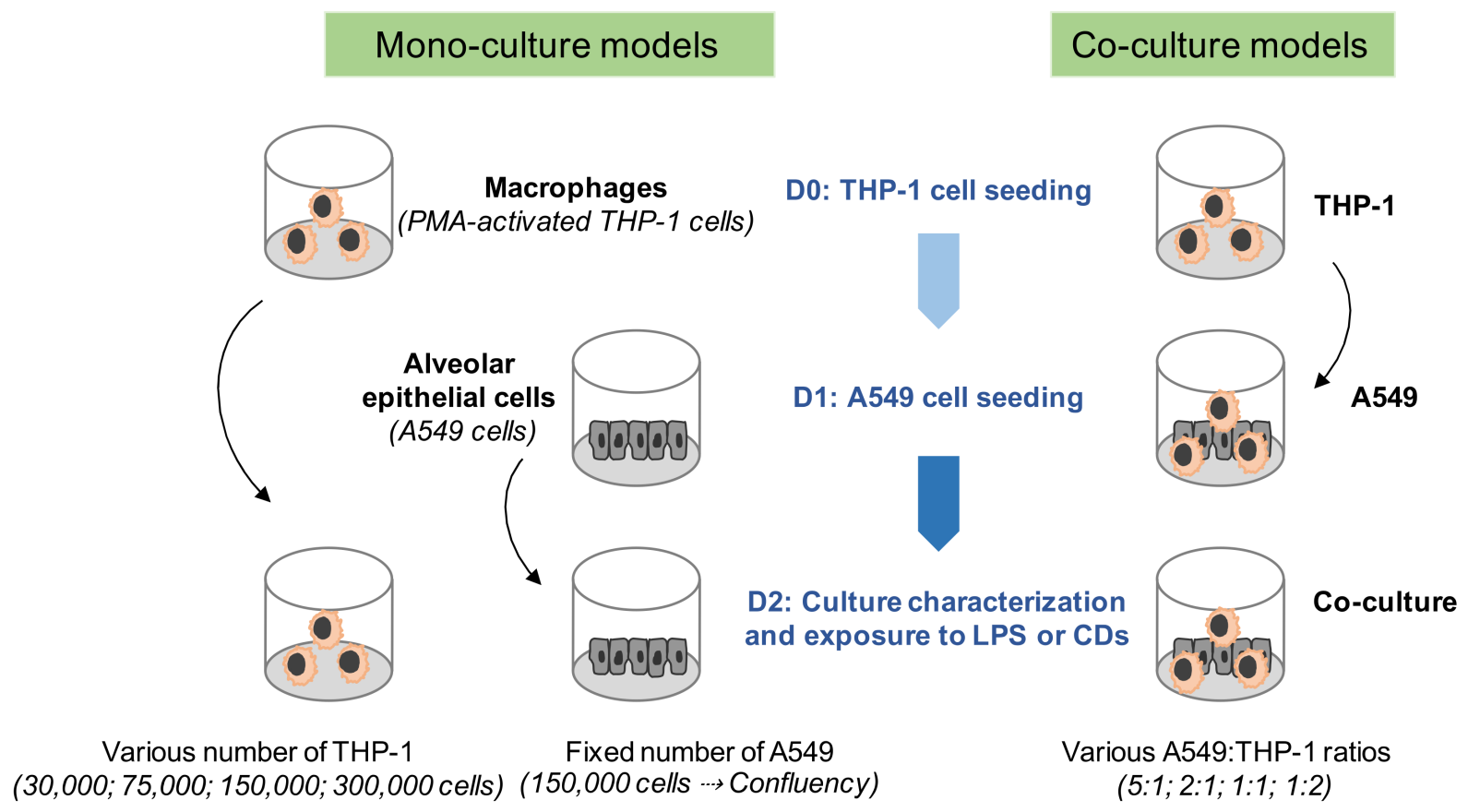

Figure 1. Schematic representation of the mono- and co-culture models used to assess the biological responses evoked by the CDs.

\subsection{Cell Exposure to $C D s$}

Once mono- and co-cultures were established, the media was removed and replaced with $400 \mu \mathrm{L}$ of complete culture medium containing $0.01 \mu \mathrm{g} / \mathrm{mL}$ lipopolysaccharide (LPS, Escherichia coli O55:B5, Sigma-Aldrich, St. Louis, MO, USA) or CDs at the desired concentrations. Cells were exposed for $4 \mathrm{~h}$ before assessing NP internalization, cell death mechanisms and oxidative stress, and for $24 \mathrm{~h}$ before measuring cellular viability and pro-inflammatory cytokine production.

\subsection{Cell Viability Assay}

Changes in cell viability in response to CDs were assessed by the MTT (3-[4,5dimethylthiazol-2-yl]-2,5 diphenyltetrazolium bromide) assay. Mono- and co-cultures were incubated with $400 \mu \mathrm{L}$ of increasing concentrations of CDs $(3-200 \mu \mathrm{g} / \mathrm{mL}$, i.e., $0.6-40 \mu \mathrm{g} / \mathrm{cm}^{2}$ ) for $24 \mathrm{~h}$. After this, cellular supernatant was removed and stored at $-20{ }^{\circ} \mathrm{C}$ until cytokine assay, and cells were washed with PBS before addition of culture medium containing MTT $(1.0 \mathrm{mg} / \mathrm{mL}, 300 \mu \mathrm{L})$. After incubation for $1 \mathrm{~h}$, the MTT solution was removed, and cells were lysed with DMSO $(500 \mu \mathrm{L})$. Absorbance of the resulting samples was read at $570 \mathrm{~nm}$ with a correction at $690 \mathrm{~nm}$ using a Multiskan FC reader (Thermo Scientific, Illkirch-Graffenstaden, France). Cell viability was expressed as the percentage of the absorbance of CD-treated cells relative to the absorbance of untreated cells.

\subsection{Assessment of Cell Death Mechanisms}

FACS was used to assess cell death mechanisms induced by CDs, as described by Grabowski et al. [24]. Mono- and co-cultures were incubated with $400 \mu \mathrm{L}$ of 50 or $200 \mu \mathrm{g} / \mathrm{mL}$ (i.e., 10 or $40 \mu \mathrm{g} / \mathrm{cm}^{2}$ ) of CDs for $4 \mathrm{~h}$. After CD exposure, the supernatant was discarded and cells were rinsed with PBS and harvested by $0.05 \%$ trypsin treatment. The cells were then stained with an APC-Cy7 anti-human CD14 antibody as previously described to distinguish macrophages from epithelial cells. Besides, to investigate the occurrence of apoptosis and/or necrosis, a doubled staining procedure using FITC-Annexin V (BioLegend, San Diego, CA, USA) and propidium iodide (BD Biosciences, Le Pont de Claix, France) was performed according to the manufacturer's instructions. The fluorescence of each sample (30,000 events) was collected using an APC-Cy7 (red laser) channel 
(macrophage identification), as well as FITC (blue laser) and PE-Texas Red (yellow-green laser) channels (apoptosis and/or necrosis detection).

\subsection{Oxidative Stress Assessment}

Oxidative stress was assessed by FACS. Mono- and co-cultures were incubated with $400 \mu \mathrm{L}$ of 50 or $200 \mu \mathrm{g} / \mathrm{mL}$ (i.e., 10 or $40 \mu \mathrm{g} / \mathrm{cm}^{2}$ ) of CDs for $4 \mathrm{~h}$. After CD exposure, the supernatant was discarded and cells were rinsed with PBS and harvested by $0.05 \%$ trypsin treatment. The cells were stained with the APC-Cy7 anti-human CD14 antibody as previously described. Next, reactive oxygen species (ROS) production in response to CDs was measured using the fluorescent probe CellROX ${ }^{\mathrm{TM}}$ Orange (Invitrogen ${ }^{\mathrm{TM}}$, Thermo Scientific, Illkirch-Graffenstaden, France). Briefly, cells were incubated with culture medium containing $5 \mu \mathrm{M}$ of the probe for $30 \mathrm{~min}$ and then rinsed twice with PBS before flow cytometry analysis. The fluorescence of each sample (30,000 events) was collected using an APC-Cy7 (red laser) channel (macrophage identification) and a PE (yellow-green laser) channel (ROS detection). Results were expressed as the fold change in fluorescence intensity of CD-exposed cells relative to the fluorescence intensity of non-exposed control cells.

\subsection{Assessment of CD Cell Uptake}

FACS and 3-D confocal laser scanning microscopy (CLSM) were used to assess CD uptake by cells, as described previously in the literature $[24,26]$. For FACS, mono- and co-cultures were incubated with $400 \mu \mathrm{L}$ of $25 \mu \mathrm{g} / \mathrm{mL}$ (i.e., $5 \mu \mathrm{g} / \mathrm{cm}^{2}$ ) of CDs for $4 \mathrm{~h}$. Then, the supernatant was discarded, cells were rinsed with PBS, harvested by $0.05 \%$ trypsin treatment, and stained with the APC-Cy7 anti-human CD14 antibody as previously described. The fluorescence of each sample (30,000 events) was collected using an APC-Cy7 (red laser) channel (macrophage identification) and a BV421 (violet laser) channel (CD detection). $C D$ uptake was quantified by determining changes in the mean fluorescence intensity (MFI) of CD-exposed cells compared to the non-exposed control cells. For CLSM experiments, cells were seeded into 8 -well IbiTreat $\mu$-Slides $\left(1.5\right.$ polymer coverslip, IBIDI ${ }^{\circledR}$, Ibidi $\mathrm{GmbH}$, Gräfelfing, Germany) and incubated with $25 \mu \mathrm{g} / \mathrm{mL}$ of CDs for $4 \mathrm{~h}$. At the end of the incubation period, the cells were carefully washed with PBS containing $0.5 \%$ BSA before staining for $1 \mathrm{~h}$ with the Alexa Fluor ${ }^{\circledR} 700$-labeled anti-human CD14 antibody to identify THP-1-derived macrophages. After staining, cells were rinsed with PBS and the M488 fluorescent probe (200 nM in PBS) was added to the samples for $5 \mathrm{~min}$ to label the cell membrane [40]. Then, the intracellular localization of CDs was observed using a Leica SP2 microscope equipped with a $63 \times$ oil immersion objective (numerical aperture $=1.2$ ). CDs, the anti-human CD14 antibody, and the M488 membrane probe were excited with 405,635 and $488 \mathrm{~nm}$ laser sources, respectively.

\subsection{Cytokine Assay}

Interleukine-8 (IL-8) and monocyte chemoattractant protein 1 (MCP-1) were quantified in cell culture supernatants by ELISA according to the manufacturer's instructions (R\&D Systems, Lille, France).

\subsection{Presentation and Statistical Analysis of the Data}

Data were expressed as mean \pm SEM and plotted as concentration-response curves or bar charts. Statistical differences between groups were determined by analysis of variance (ANOVA) followed by Tukey's tests, using the GraphPad Prism software (v 6.0, San Diego, CA, USA). Data were considered as significantly different when the $p$ value was less than 0.05 .

\section{Results and Discussion}

\subsection{Physicochemical Characterization of $C D s$}

In this study, one $\mathrm{CD}$ exhibited a negative surface charge $(\mathrm{CD}-\mathrm{COOH}, \zeta=-43.3 \pm 3.2$ $\mathrm{mV})$, and the other three were positively charged (CD-PEI600, $\zeta=+31.8 \pm 1.1 \mathrm{mV}$; CD- 
PEHA, $\zeta=+29.2 \pm 2.2 \mathrm{mV}$; CD-DMEDA, $\zeta=+11.1 \pm 2.2 \mathrm{mV}$ ). The surface charge density of the cationic CDs increased with the nitrogen content of the passivation agent used for their synthesis, with the $Q_{e k}$ value ranging from $0.01 \mu \mathrm{mol} / \mathrm{mg}$ for CD-DMEDA to $4.70 \mu \mathrm{mol} / \mathrm{mg}$ for CD-PEI600 (Table 1). The mean hydrodynamic diameter of the cationic CDs ranged from 10.2 to $28.7 \mathrm{~nm}$, while the anionic $\mathrm{CD}-\mathrm{COOH}$ had a mean hydrodynamic diameter of around $50 \mathrm{~nm}$, revealing a stronger tendency to aggregate for this $\mathrm{CD}$ (Table 1). The CDs showed a UV-vis absorption peak at $350 \mathrm{~nm}$, except for CD-DMEDA and CD$\mathrm{COOH}$, which absorbed decreasingly between 250 and $800 \mathrm{~nm}$. The fluorescence emission and excitation spectra recorded on CD solutions revealed homogeneous optical properties between the four NPs, with a maximum fluorescence excitation and emission wavelengths at around 365 and $460 \mathrm{~nm}$, respectively (Table 1). These intrinsic photoluminescence properties make it possible to analyze the cellular uptake of CDs with no conjugation to a fluorescent label required.

Table 1. Physicochemical characteristics of the CDs investigated herein.

\begin{tabular}{|c|c|c|c|c|}
\hline Characteristics & CD-PEI600 & CD-PEHA & CD-DMEDA & $\mathrm{CD}-\mathrm{COOH}$ \\
\hline $\begin{array}{l}\text { Zeta potential } \\
\zeta(\mathrm{mV})\end{array}$ & $+31.8 \pm 1.1$ & $+29.2 \pm 2.2$ & $+11.1 \pm 2.2$ & $-43.3 \pm 3.2$ \\
\hline $\begin{array}{l}\text { Surface charge density } Q_{e k} \\
(\mu \mathrm{mol} / \mathrm{mg})\end{array}$ & 4.70 & 3.25 & 0.01 & - \\
\hline $\begin{array}{l}\text { Hydrodynamic diameter } \\
\text { D (nm) }\end{array}$ & $11.0 \pm 3.4$ & $10.2 \pm 3.2$ & $28.7 \pm 4.1$ & $50.7 \pm 0.9$ \\
\hline $\begin{array}{l}\text { Photoluminescence } \\
\lambda_{\max } / \lambda_{\mathrm{ex}} / \lambda_{\mathrm{em}}(\mathrm{nm})\end{array}$ & $350 / 365 / 460$ & $350 / 370 / 465$ & a $/ 315 / 465$ & $\mathrm{a} / 370 / 445$ \\
\hline
\end{tabular}

${ }^{a}$ : Monotone and decreasing UV-vis absorption between 250 and $800 \mathrm{~nm}$.

\subsection{Characteristics of the Co-Culture According to the A549:THP-1 Seeding Ratio}

Based on the literature, four A549:THP-1 seeding ratios were used to create our coculture model: 5:1 [22], 2:1 [21,23,24], 1:1 [25], and 1:2 [26]. By modulating the proportion of epithelial cells to macrophages, it is possible to mimic physiological or inflammatory conditions. Indeed, in a healthy individual, 9.4\% of lung cells are macrophages [41], whereas under pathological conditions or depending on individual lifestyle (smoker or not), the number of alveolar macrophages increases [42]. To characterize the four obtained models, we first quantified the proportion of macrophages inside the co-cultures at the time of their use, i.e., two days after THP-1 seeding (Figure 1), since the A549:THP-1 ratio may vary over time due to the proliferation of epithelial cells, unlike macrophages. To do so, we used a CD14 staining strategy that made it possible to discriminate the A549 epithelial cells (CD14 negative) from the THP-1-derived macrophages (CD14 positive) by FACS (Figure 2a). As shown on Figure 2b, the proportion of macrophages in our co-cultures increased when the A549:THP-1 ratio decreased, as expected, and reached 5\%, $14 \%, 27 \%$, and $45 \%$ for the initial A549:THP-1 seeding ratio of 5:1; $: 1 ; 1: 1$, and 1:2, respectively. Taking into account a proportion of $9.4 \%$ macrophages in the lung tissue of healthy individuals [41], in our study, the A549:THP-1 seeding ratio of 2:1 appeared to best mimic physiological conditions. This A549:THP-1 ratio of 2:1 is one of the most widely used in studies based on co-culture models $[21,23,24]$. However, although it is important to identify the real proportion of macrophages at the time of exposure to the respiratory toxicants, such a macrophage quantification within epithelial cell-macrophage co-culture models has been rarely reported in the literature [26]. 
(a)
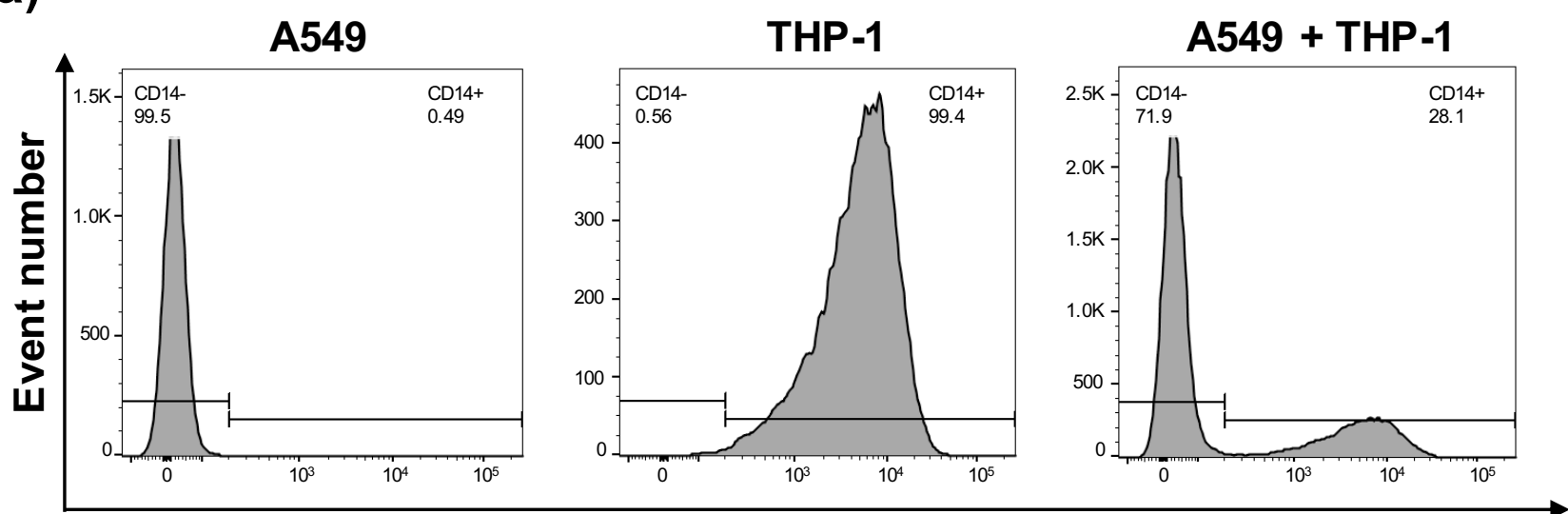

CD14 (APC-Cy7)

(b)

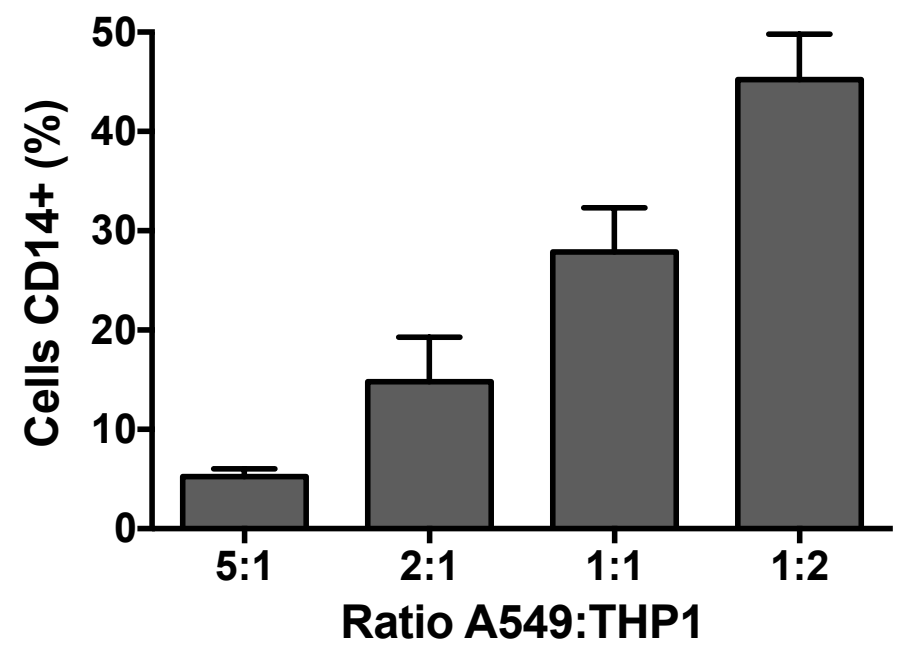

Figure 2. Determination of the proportion of macrophages in the co-culture models by FACS. (a) Staining and gating strategy to discriminate the A549 epithelial cells (CD14-) from the THP-1-derived macrophages (CD14+). (b) Proportion of macrophages (CD14+ cells) within the co-culture according to the A549:THP-1 seeding ratio two days after THP-1 seeding. Data are means \pm SEM of $n=3$ experiments.

We then continued the characterization of our co-culture models by assessing their capacity to respond to LPS, a well-known pro-inflammatory stimulus. Thus, the secretion of the pro-inflammatory cytokine IL-8 was measured in the supernatants of mono- and co-cultures exposed to $0.01 \mu \mathrm{g} / \mathrm{mL}$ LPS (Figure 3). The response of the co-cultures was compared to that of the corresponding mono-cultures. After exposure to LPS, the level of IL-8 secretion was low in the A549 mono-culture $(<500 \mathrm{pg} / \mathrm{mL}$, not significant), whereas all the THP-1 mono-cultures secreted significant levels of the cytokine. As expected, in the THP-1 mono-cultures, IL-8 secretion induced by LPS increased as a function of cell number per well, reaching around $6500,12,000,22,000$, and $63,000 \mathrm{pg} / \mathrm{mL}$ at the cell density of $30,000,75,000,150,000$, and 300,000 cells/well, respectively. In the co-cultures, secretion of IL-8 in response to LPS was greater than in the corresponding mono-cultures, whatever the A549:THP-1 seeding ratio. Thus, the co-cultures were able to respond to a pro-inflammatory stimulus, which is consistent with the literature data [24,43-45]. Furthermore, the cocultures more markedly responded to LPS compared to the corresponding THP-1 monocultures $(p<0.001)$, except at the A549:THP-1 seeding ratio of 1:2, suggesting a possible collaboration between epithelial cells and macrophages. Such a synergistic inflammatory response has already been described in the literature upon exposure of a A549:THP-1 co-culture to pathogens such as Streptococcus pneumoniae [44] or respiratory syncytial 
virus [46]. Some collaboration mechanisms between epithelial cells and macrophages have been proposed, which could involve activation of the NLRP3 inflammasome [21,47] or the TLR receptors [48]. Based on these characterization data, the co-culture model with the A549:THP-1 seeding ratio of 2:1 was selected to assess CD biological effects, as it better mimics the in vivo conditions in terms of the NP target cell ratio while appropriately responding to a pro-inflammatory stimulus.
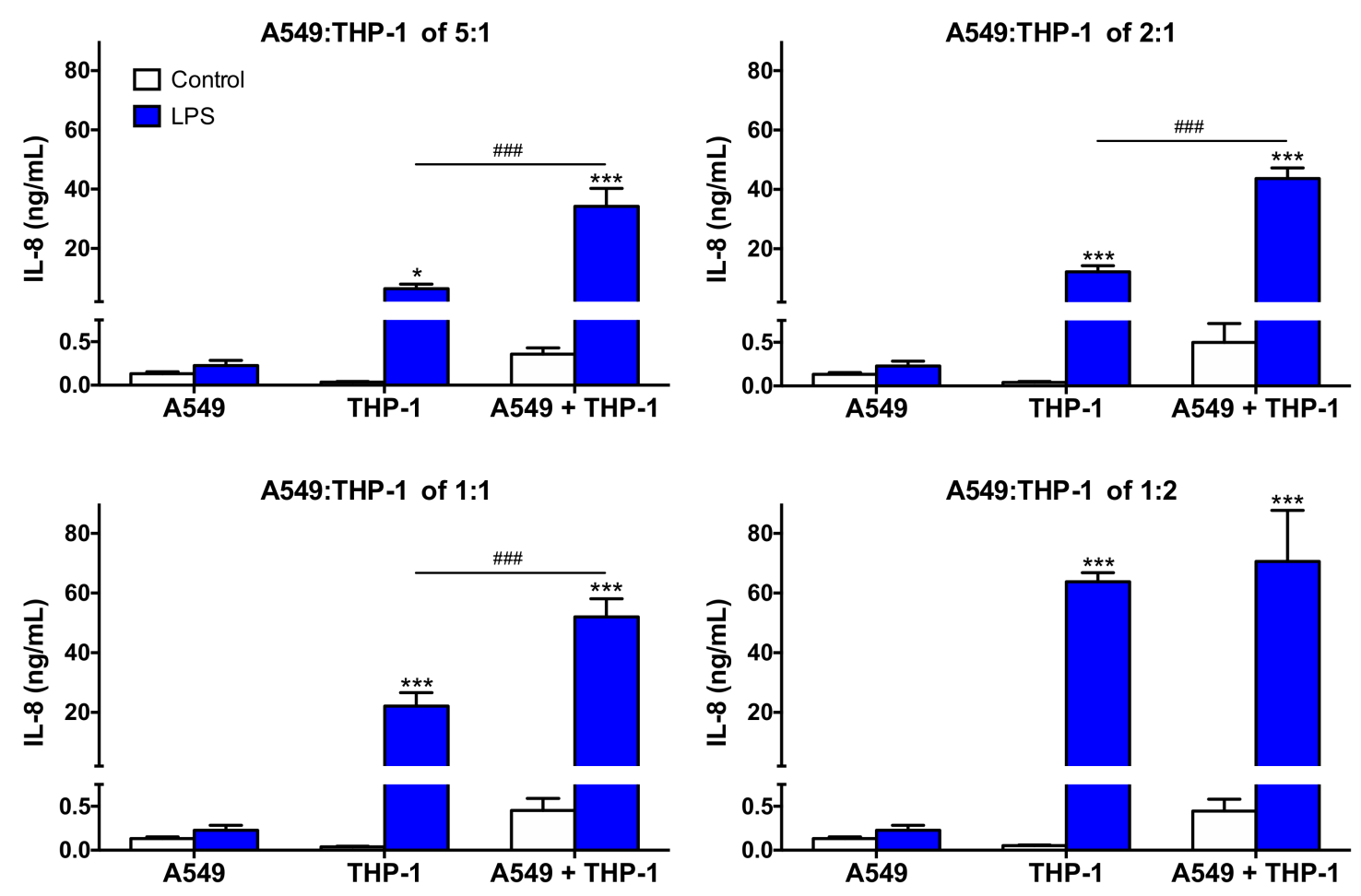

Figure 3. Capacity of the co-culture models to respond to a pro-inflammatory stimulus. Mono- and co-cultures were exposed to $0.01 \mu \mathrm{g} / \mathrm{mL}$ of LPS for $24 \mathrm{~h}$, and the secretion of the pro-inflammatory cytokine IL- 8 was measured in the culture supernatants. Data are means \pm SEM of $n=3$ experiments. Statistical differences at $p<0.05$ (one symbol) and $p<0.001$ (three symbols) were determined by ANOVA followed by the Tukey's test when compared to control unexposed cells (asterisks) or to LPS exposed-THP-1 mono-culture (hash).

\subsection{Cytotoxicity of CDs and Cell Death Mechanisms in Mono- and Co-Cultures}

To evaluate CD cytotoxicity, mono- and co-cultures (A549:THP-1 at seeding ratio of 2:1) were exposed to increasing concentrations (3-200 $\mu \mathrm{g} / \mathrm{mL}$ ) of CD-PEI600, CD-PEHA, CD-DMEDA, or CD-COOH for $24 \mathrm{~h}$, before assessing cell viability using the MTT assay. As shown in Figure 4, CD-PEI600 $\left(\zeta=+31.8 \mathrm{mV} ; \mathrm{Q}_{\mathrm{ek}}=4.70 \mu \mathrm{mol} / \mathrm{mg}\right)$ induced a decrease in cell viability that reached $100 \%$ at the concentration of $200 \mu \mathrm{g} / \mathrm{mL}$ in both monoand co-cultures. A loss of viability was also observed with CD-PEHA $(\zeta=+29.2 \mathrm{mV}$; $\mathrm{Q}_{\mathrm{ek}}=3.25 \mu \mathrm{mol} / \mathrm{mg}$ ) but to a lesser extent and only in the THP-1 mono-culture. No cytotoxicity was observed for CD-DMEDA $\left(\zeta=+11.1 \mathrm{mV} ; \mathrm{Q}_{\mathrm{ek}}=0.01 \mu \mathrm{mol} / \mathrm{mg}\right)$ and CD$\mathrm{COOH}(\zeta=-43.3 \mathrm{mV})$ in any cellular model. Thus, the anionic $\mathrm{CD}$ induced no cytotoxic effect and among the three cationic CDs, the one with the highest surface charge density exhibited the most potent toxicity whatever the culture model. In the literature, a greater toxicity of positive CDs compared to negative ones was reported $[38,49,50]$. However, our group also recently demonstrated that a positive zeta potential for NPs does not necessarily translate into toxicity, and that the surface charge density of NPs influences their toxicity as well [39], which is confirmed in this present study. Regarding the cellular models, the viability loss induced by CD-PEI600 and CD-PEHA was greater in THP-1 than in A549 mono-cultures. These data are in line with the literature reporting that macrophages are more sensitive to NP toxicity than lung epithelial cells $[23,39,51,52]$. This could be explained 
by the fact that macrophages internalize more NPs than epithelial cells, as we will discuss below. Surprisingly, when THP-1 cells were combined with A549 cells in a co-culture, no viability loss (CD-PEHA) or viability loss similar to that in the A549 mono-culture (CD-PEI600) was measured. These results are in keeping with the data reported by other groups on polystyrene [23] or silver [51] NPs, suggesting that the co-culture model would be less relevant than the macrophages in mono-culture for assessing the cytotoxicity of NPs. However, this hypothesis is based on data from the MTT colorimetric viability assay, which may be altered by disturbances in cell metabolism or interference with test compounds including NPs [53]. Besides, this method does not allow to discriminate of the viability of either cell type within the co-culture.
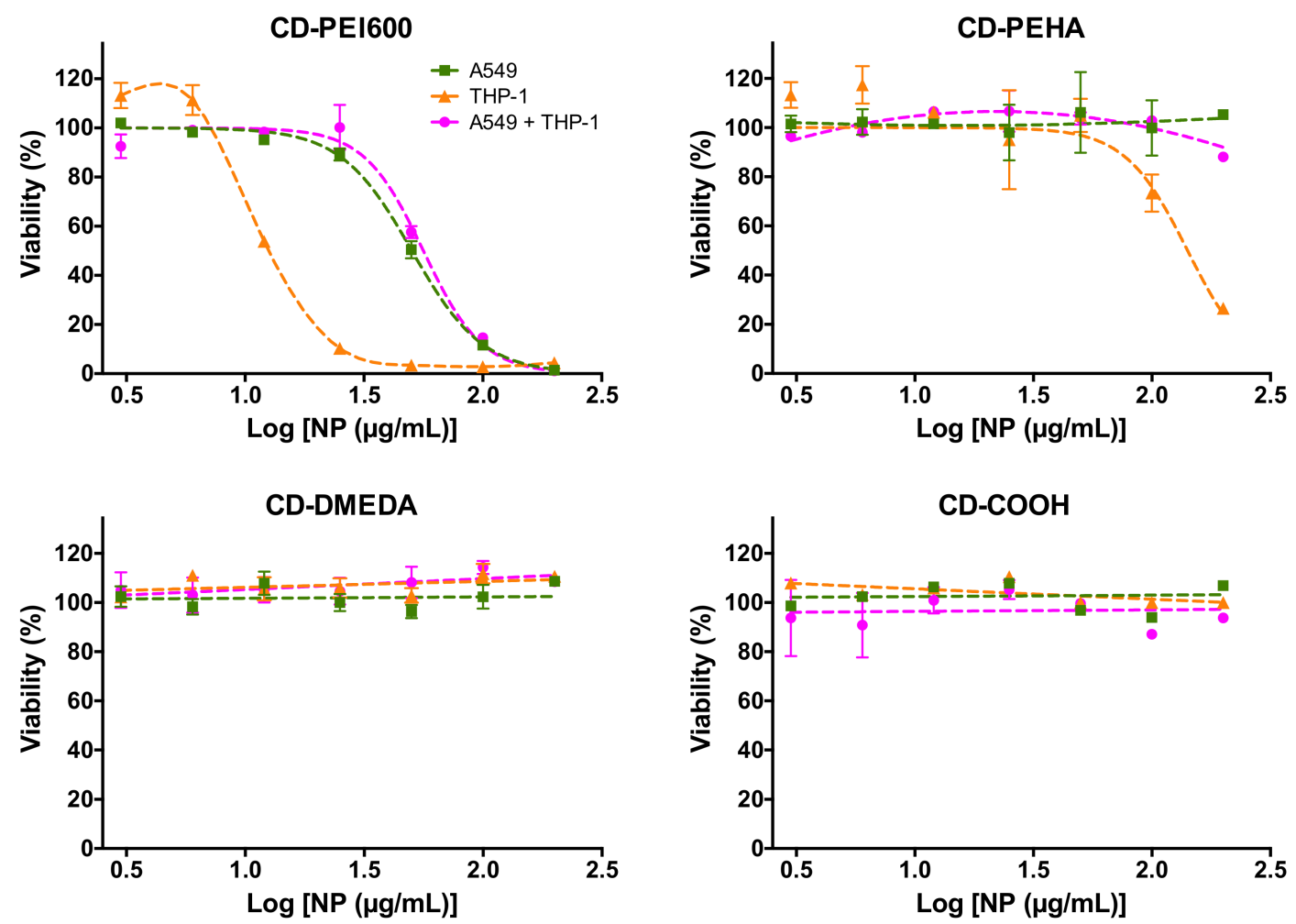

Figure 4. Cytotoxicity of the CDs in mono- and co-cultures. Mono- and co-cultures (A549:THP-1 seeding ratio of 2:1) were exposed to increasing concentrations (3-200 $\mu \mathrm{g} / \mathrm{mL}$ ) of CD-PEI600, CD-PEHA, CD-DMEDA, or CD-COOH for $24 \mathrm{~h}$, and cell viability was assessed with the MTT assay. Results are expressed as the percentage of viability when compared to the control (unexposed cells). They are means \pm SEM of $n=3-6$ experiments. Concentration-response curves were obtained after logarithmic transformation of the data and fit with the Hill equation.

To address this point, we assessed the cytotoxicity and the cell death mechanisms induced by the CDs in each cell type within the co-culture. This was performed through FACS experiments using the CD14 fluorescence labeling (Figure 2a). In the two identified cell populations, the cell death induced by CDs was assessed by combined fluorescence analysis of the annexin $\mathrm{V}$ apoptosis (X-axis) and propidium iodide necrosis markers ( $\mathrm{Y}$-axis) (Figure 5a). Mono-cultures were analyzed in the same way (data not shown). None of the CDs evoked cell apoptosis whatever the culture model. In contrast, as shown in Figure $5 b$, cationic CDs with the highest charge density (CD-PEI600) induced potent necrosis of THP-1 cells in the mono- and co-culture models, with no difference between the two models. Thus, macrophages were equally sensitive to the $\mathrm{CD}$ toxicity whether they were tested in monoor co-culture. Besides, we showed that the macrophage cell death mechanism involved necrosis. In the literature, there are some conflicting data about the necrotic effects of NPs because most studies only report cell viability loss without focusing on cell death mode [54]. However, in line with our data, Wei et al. demonstrated that cationic NPs induce cell 
necrosis in alveolar macrophages from mouse lung and that this effect is dependent on the NP cationic surface charge [55]. In this study, cationic NPs (based on PEI or chitosan) lead to rapid necrosis through impairment of $\mathrm{Na}^{+} / \mathrm{K}^{+}$-ATPase. Another pathway involved in necrosis induced by NPs is NP degradation in lysosomes and subsequent destabilization of this organelle leading to the release of toxic substances into the cytosol and finally cell necrosis. Based on our previous studies on PEI-based CDs [56], we assume that the presence of many polyamine decorations at the surface of CD-PEI600 may promote such a toxicity mechanism in macrophages. In summary of this part, we showed that the cytotoxicity of CDs was dependent on their surface charge density. If the anionic CD did not induce any cytotoxic effect, we provided a ranking of the toxicity of the three cationic $\mathrm{CDs}$ that parallels their positive surface charge density, i.e., CD-PEI600 >> CD-PEHA > CD-DMEDA, with no toxicity of CD-DMEDA. In this cytotoxicity evaluation, the analysis of annexin $\mathrm{V}$ and propidium iodide markers by FACS was applicable to all cell models, in contrast to the MTT assay, which is better suited to mono-culture models. No added value of the co-culture model compared to macrophages in mono-culture was obtained.

(a)

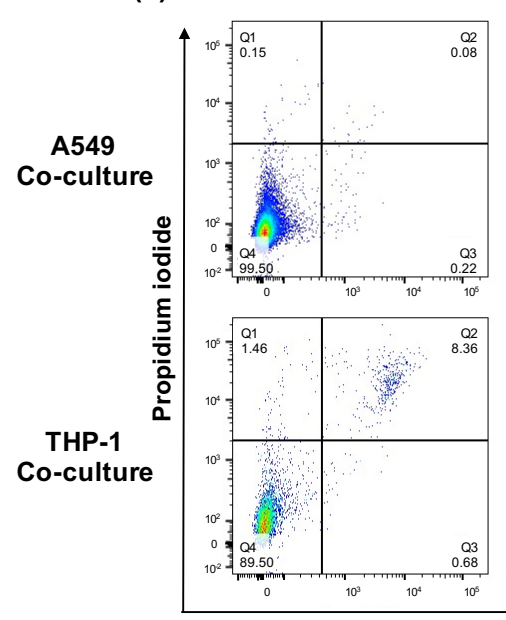

CD-PEI600
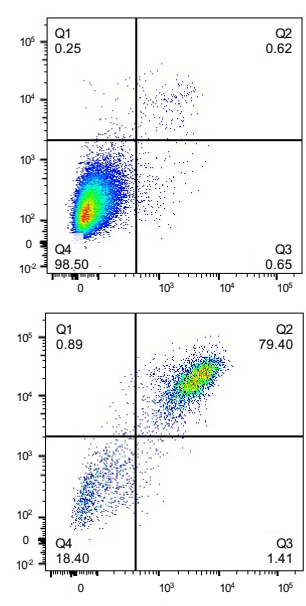

CD-PEHA
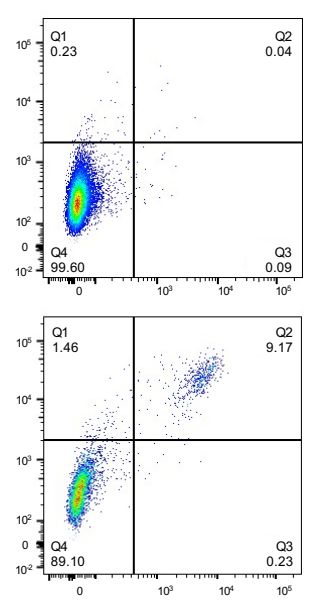

Annexin V
CD-DMEDA
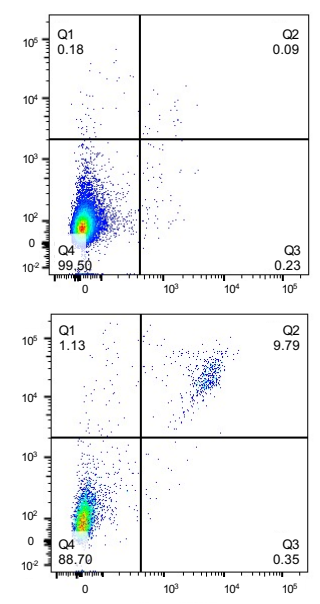

CD-COOH

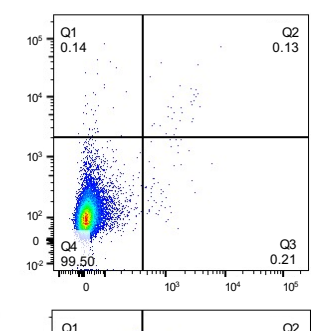

(b)

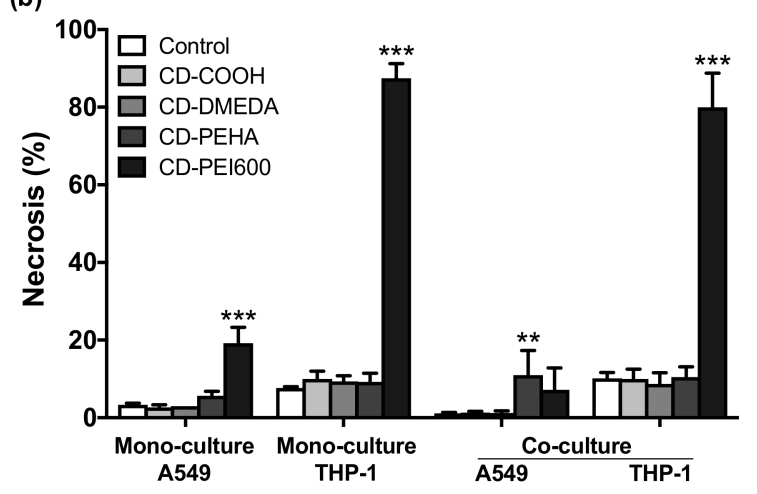

Figure 5. Cell death mechanisms evoked by CDs towards mono- and co-cultures. Mono- and co-cultures (A549:THP-1 seeding ratio of 2:1) were exposed to $50 \mu \mathrm{g} / \mathrm{mL}$ (CD-PEI600) or $200 \mu \mathrm{g} / \mathrm{mL}$ (CD-PEHA, CD-DMEDA and CD-COOH) for $4 \mathrm{~h}$, and apoptosis/necrosis were assessed in each cell type by FACS. (a) Cell death mechanisms assessed by combined fluorescence analysis of the Annexin V apoptosis marker (X-axis) and propidium iodide necrosis marker (Y-axis) into A549 (CD14-) and THP-1 (CD14+) populations within the co-culture (data from $n=1$ experiment). (b) Cellular mortality by necrosis in mono-culture and the co-culture, as expressed as the percent of double positive cells. Data are means \pm SEM of $n=3-5$ experiments. Statistical differences when compared to control unexposed cells were determined by ANOVA followed by the Tukey's test. ${ }^{* *} p<0.01 ; * * * * 0.001$. 


\subsection{Internalization of CDs in the Different Culture Models and Cell Types}

As cell uptake drives NP toxicity [57], we investigated the internalization of CDs by epithelial cells and macrophages in our different culture models. Mono- and co-cultures were exposed to $25 \mu \mathrm{g} / \mathrm{mL}$ of CDs for $4 \mathrm{~h}$ and CD uptake by A549 and THP- 1 cells was assessed by monitoring CD-associated fluorescence by FACS and CLSM after cell staining with a cell membrane fluorescent probe (M488) and/or APC-Cy7 anti-CD14 antibody. As shown in Figure 6a,b, no fluorescence increase was observed in cells exposed to the anionic $\mathrm{CD}-\mathrm{COOH}$. In contrast, an increase in CD fluorescence signal was measured in A549 and THP-1 cells treated with cationic CDs in both mono- and co-culture models, with greater uptake of the highly positively charged CD-PEI600. Following observation of the co-culture by 3-D CLSM (Figure 6c), CD-PEI600 was visible as blue spots in the cytoplasm of epithelial cells (membrane in green) and macrophages (membrane in red), which confirmed the uptake of this cationic CDs by the two cell types within the co-culture model. Thus, a direct correlation was observed between the uptake of CDs and their toxicity profile, confirming the influence of the NP zeta potential [58] but also of the NP positive surface charge density [39] on these effects. In the literature, it has already been reported that a cationic surface charge could promote NP interactions with negatively charged serum proteins and therefore facilitate NP internalization by macrophages, in particular via phagocytosis [59]. However, whether the density of positive charges on the NP surface can impact the protein corona remains poorly explored [60] and will be an interesting focus for future research in the field.

(a)

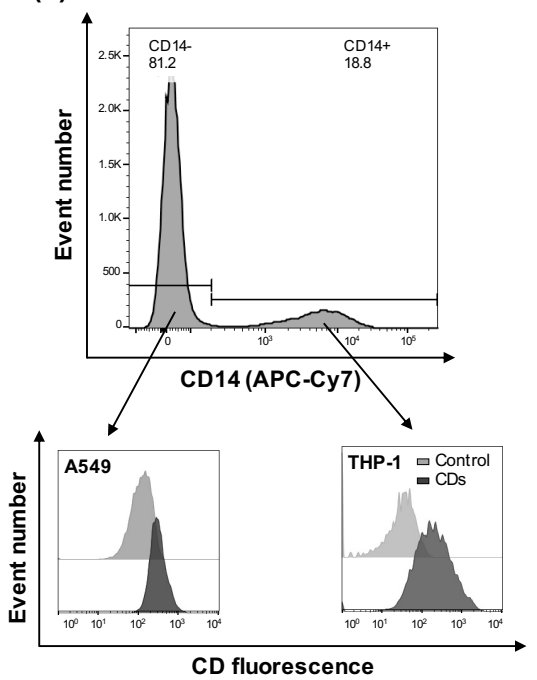

(b)
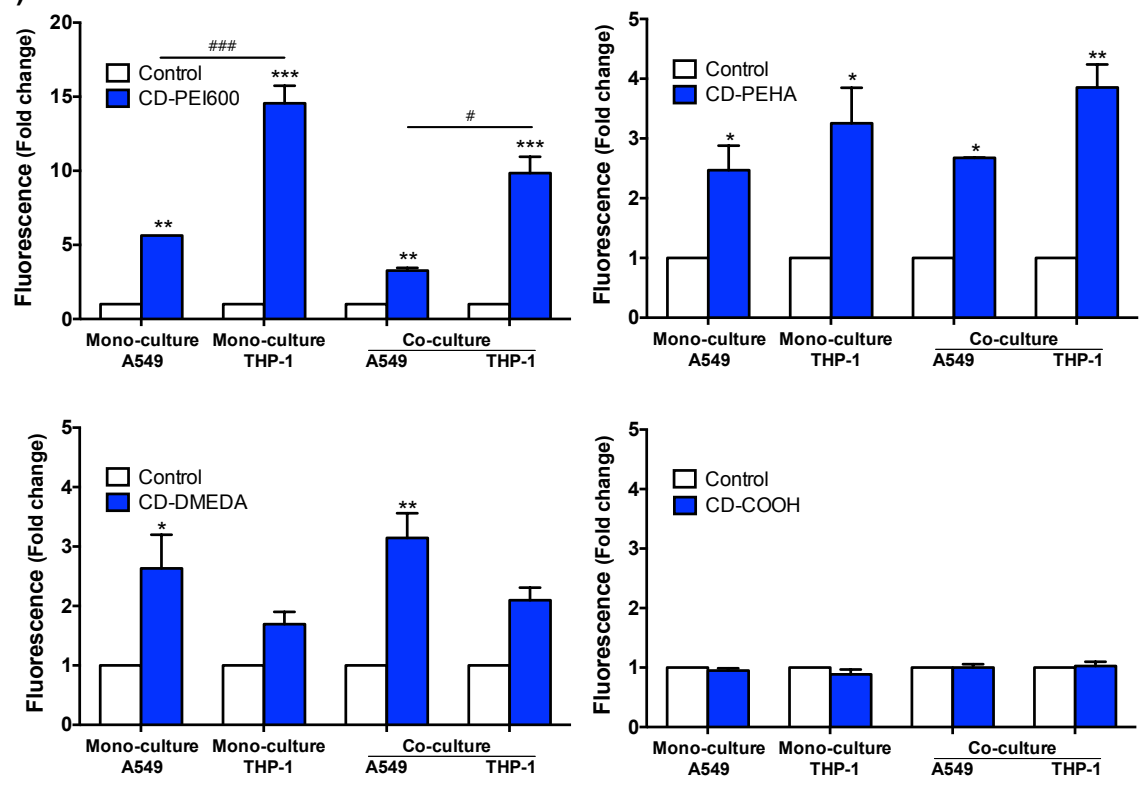

Figure 6. Cont. 
(c)

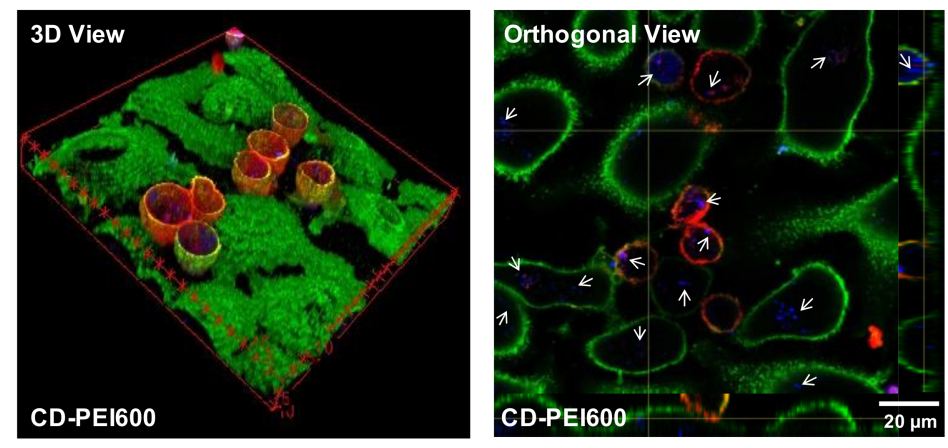

Figure 6. Uptake of CDs in the different culture models and cell types. Mono- and co-cultures (A549:THP-1 seeding ratio of 2:1) were exposed to $25 \mu \mathrm{g} / \mathrm{mL}$ of CDs for $4 \mathrm{~h}$, and CD-uptake was assessed by FACS or 3-D CLSM. (a) Gating strategy to identify the two cell types present within the co-culture and to measure CD cell uptake by FACS after cell staining with an APC-Cy7 anti-CD14 antibody (data from $n=1$ experiment). (b) Quantification of CD internalization by FACS. Results are expressed as fold change in fluorescence intensity when compared to control cells, and are means \pm SEM of $n=3$ experiments. Statistical differences at $p<0.05$ (one symbol), $p<0.01$ (two symbols) and $p<0.001$ (three symbols) were determined by ANOVA followed by the Tukey's test when compared to control unexposed cells (asterisks) or to CD-exposed A549 cells (hash). (c) 3D view (left, composite of full z-stack) and orthogonal view (right, $x z$ and $y z$ micrograph obtained from an optical slice of a z-stack) from CLSM observation of the co-culture exposed to $25 \mu \mathrm{g} / \mathrm{mL}$ of CD-PEI600 for $4 \mathrm{~h}$. Cells were stained with the fluorescent membrane probe M488 and an anti-human CD14 antibody before observation. A549 cell membrane is colored in green, THP-1 cell membrane is colored in red, and CDs appear in blue and are indicated by white arrows (scale bar $=20 \mu \mathrm{m}$ ).

Regarding the cellular models, we noted that CD-PEI600 uptake was higher in macrophages than in epithelial cells, both in mono- $(p<0.001)$ and co-cultures $(p<0.05)$. This result is in agreement with data from the literature on the internalization of PLGA [24], $\mathrm{TiO}_{2}$ and $\mathrm{SiO}_{2}$ [26], or silver [51] NPs in co-culture models associating lung epithelial cells and macrophages. Although investigating the uptake mechanisms of CDs was beyond the goal of the present work, we assume that the difference in CD uptake between the two cell types is presumably due to the phagocytosis mechanism involved in NP uptake by macrophages in contrast to epithelial cells [61]. Thus, in contrast to anionic CD-COOH, all three cationic CDs were internalized by the cells, in the following order: CD-PEI600 > $\mathrm{CD}-\mathrm{PEHA} \approx \mathrm{CD}$-DMEDA. These observations were similar whatever the cellular model used. By combining the FACS and CLSM approaches, our data thus showed that the co-culture model proposed in the present work is suitable for NP uptake studies and that macrophages are the main target of CDs in this model.

\subsection{Oxidative Stress and Inflammatory Response Evoked by CDs in the Mono- and Co-Culture Models}

Oxidative stress is considered as a central mechanism of NP toxicity [62]. So, we investigated ROS production in mono- and co-cultures exposed to CDs for $4 \mathrm{~h}$ by FACS. As shown in Figure 7, the cationic CDs with the highest charge density (CD-PEI600), tested at the dose of $50 \mu \mathrm{g} / \mathrm{mL}$, induced ROS production in A549 and THP-1 mono-cultures. None of the other CDs induced significant ROS production even at the highest tested dose of $200 \mu \mathrm{g} / \mathrm{mL}$. Thus, cationic CDs with a high charge density have the capability of inducing ROS production in epithelial cells and macrophages, which could lead to cellular damages causing the necrosis that was observed. Surprisingly, no ROS increase in response to CD-PEI600 was measured in A549 and THP-1 cells when combined in the co-culture model. Although ROS production is a commonly used biomarker in nanotoxicology studies carried out on mono-culture models, it is still poorly monitored in co-culture models $[20,43,63-66]$. From the few reports found in the literature, it appears that NPs have no [66] or little impact on oxidative stress in co-culture models associating epithelial cells and macrophages $[43,63,64]$. This could be explained by the fact that the cellular interplay of the different cell types may help the cells dealing with oxidative stressors [20]. On 
the contrary, it has been recently reported that genes associated with antioxidant defense mechanisms (NFKB1, KEAP1, and NFE2L2) exerted slightly lower effects in the co-culture associating A549 and THP-1 cells as compared to the A549 mono-culture [65]. Assessing how antioxidant systems are modulated in response to CDs in mono- and co-culture models could be an interesting point to investigate in future work. Anyway, in this present study, we found no added value of the co-culture compared to mono-culture models in the oxidative stress assessment induced by CDs. Furthermore, ROS production for assessing the toxicological effects of $\mathrm{CDs}$ proved to be a low-sensitivity marker since among the four tested cationic $\mathrm{CDs}$, only the $\mathrm{CD}$ with the highest charge density induced a change in ROS production.
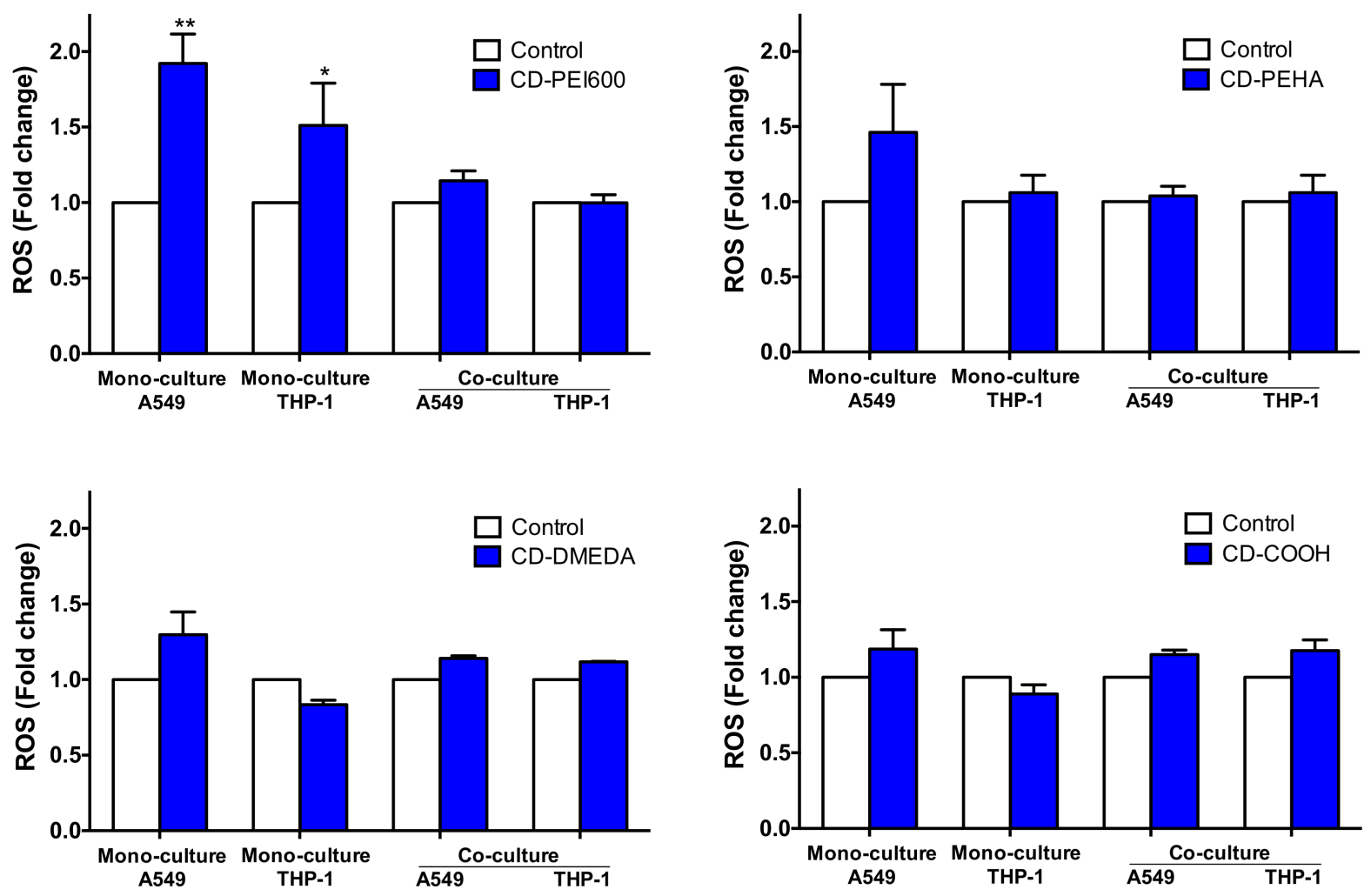

Figure 7. Oxidative stress evoked by CDs in mono- and co-cultures. Cultures were exposed to $50 \mu \mathrm{g} / \mathrm{mL}$ (CD-PEI600) or $200 \mu \mathrm{g} / \mathrm{mL}$ (CD-PEHA, CD-DMEDA and CD-COOH) for $4 \mathrm{~h}$, and ROS were measured in A549 and THP-1 mono-cultures and in A549 (CD14- cells) and THP-1 (CD14+ cells) within the co-culture (A549:THP-1 seeding ratio of 2:1) by FACS using the fluorescent probe CellROX ${ }^{\mathrm{TM}}$ Orange. Results were expressed as the fold change in the fluorescence intensity of CD-exposed cells relative to the intensity of the non-exposed control cells. Data are means \pm SEM of $n=3$ experiments. Statistical differences when compared to control unexposed cells were determined by ANOVA followed by the Tukey's test. ${ }^{*} p<0.05 ;{ }^{* *} p<0.01$. 
To investigate the inflammatory effect of CDs, the levels of IL-8 and MCP-1 were measured in the supernatants of mono- and co-cultures exposed to $\mathrm{CDs}$ at non cytotoxic concentrations (3-25 $\mu \mathrm{g} / \mathrm{mL}$, except for CD-PEI600 in the THP-1 mono-culture, Figure 4) for $24 \mathrm{~h}$ (Figure 8). The anionic $\mathrm{CD}-\mathrm{COOH}$ did not induce any pro-inflammatory effect whatever the model. Regarding the cationic CDs, an IL-8 secretion was measured in the mono-cultures incubated with those with the higher charge density (CD-PEI600), but not with those of lower charge density (CD-PEHA and CD-DMEDA) (Figure 8a). In contrast, an IL-8 secretion was observed in response to all cationic CDs in the co-culture model, with the following ranking: CD-PEI600 > CD-PEHA > CD-DMEDA. In addition, only the co-culture model showed an increase in MCP-1 secretion after exposure to cationic CDs, with the same secretion ranking between CDs than with IL-8 (Figure 8b). Thus, contrary to what was observed for oxidative stress, an increased secretion of pro-inflammatory cytokines (e.g., 20-fold for IL-8 and 10-fold for MCP-1 with CD-PEI600) was evidenced in the co-culture model compared to mono-cultures, suggesting a collaboration mechanism between macrophages and epithelial cells in response to NPs. It has been suggested that such a collaboration mechanism could involve NLRP3 inflammasome $[21,65]$ or activation of pro-inflammatory transcription factors [65]. In the literature, other studies using lung co-culture models reported significant pro-inflammatory effects of $\mathrm{SiO}_{2}$ [21,22], $\mathrm{TiO}_{2}$ [21,43], $\mathrm{CeO}_{2}$ [43], quartz [52], PLGA [24], polystyrene [67], and $\mathrm{CuO}$ [65] NPs. However, most of these studies either did not compare the inflammatory response measured in co-culture with mono-culture models or compared it only with epithelial cells and not with macrophages $[43,52,65,67]$. Among these studies, only Dekali et al. have actually demonstrated an increased inflammatory response in co-culture compared to epithelial cells and macrophages in mono-culture as we have [21]. In agreement with our data, the co-culture model of Dekali et al. was established with a A549:THP-1 seeding ratio of 2:1, suggesting that these culture conditions are well appropriate for evaluating NP-induced inflammatory responses [21]. Applied to our safety study on cationic CDs with increasing charge density, this is particularly relevant since only the co-culture model allowed us to find that $\mathrm{CDs}$ of medium (CD-PEHA) and low (CD-DMEDA) positive surface charge density could induce a pro-inflammatory response, with a greater effect for CD-PEHA compared to CD-DMEDA. If our previous work had already showed an inflammatory effect for cationic CDs with a high positive charge density [39], we report here for the firsttime a pro-inflammatory potential for cationic CDs of lower charge density. By using the co-culture model developed in this work, we also showed that the inflammatory response induced by cationic $C D$ is hierarchically related to the surface charge density of these NPs. Thus, we found a clear added value of the co-culture model compared to mono-cultures for NP-induced toxicological assessment. 
(a)
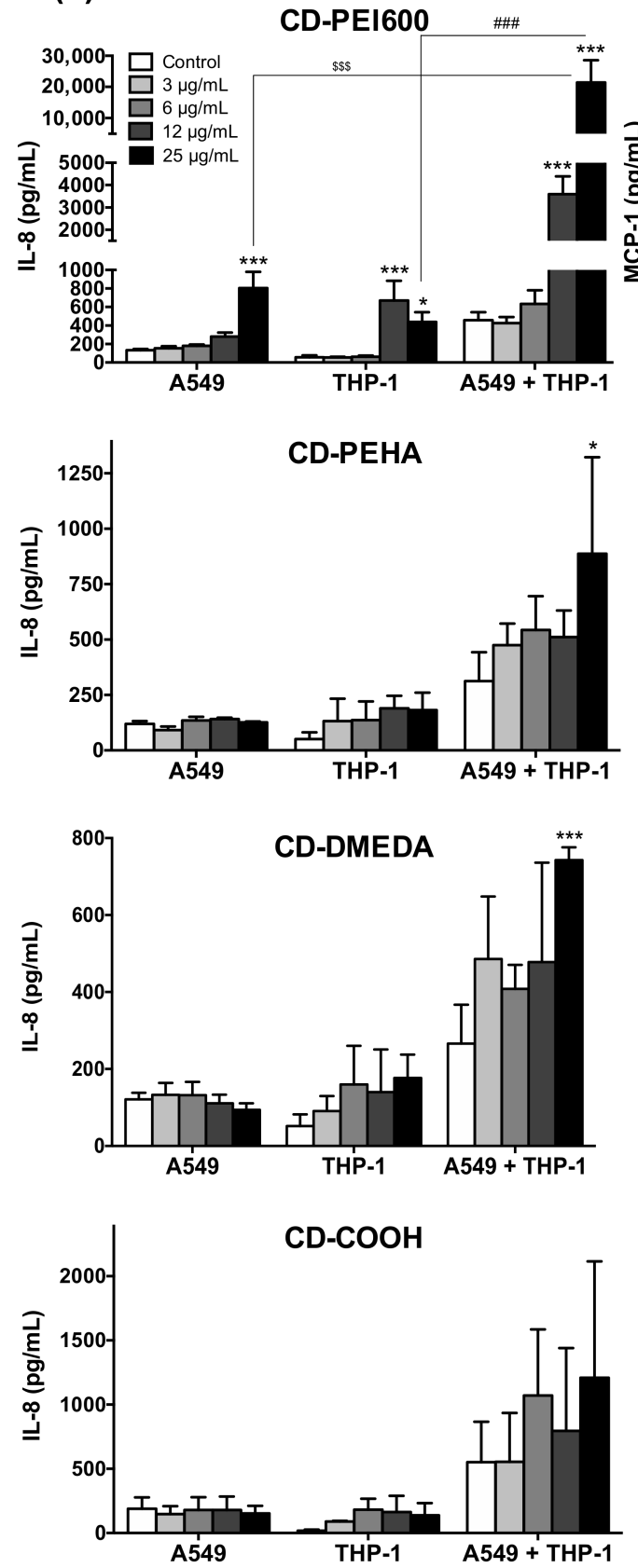

(b)
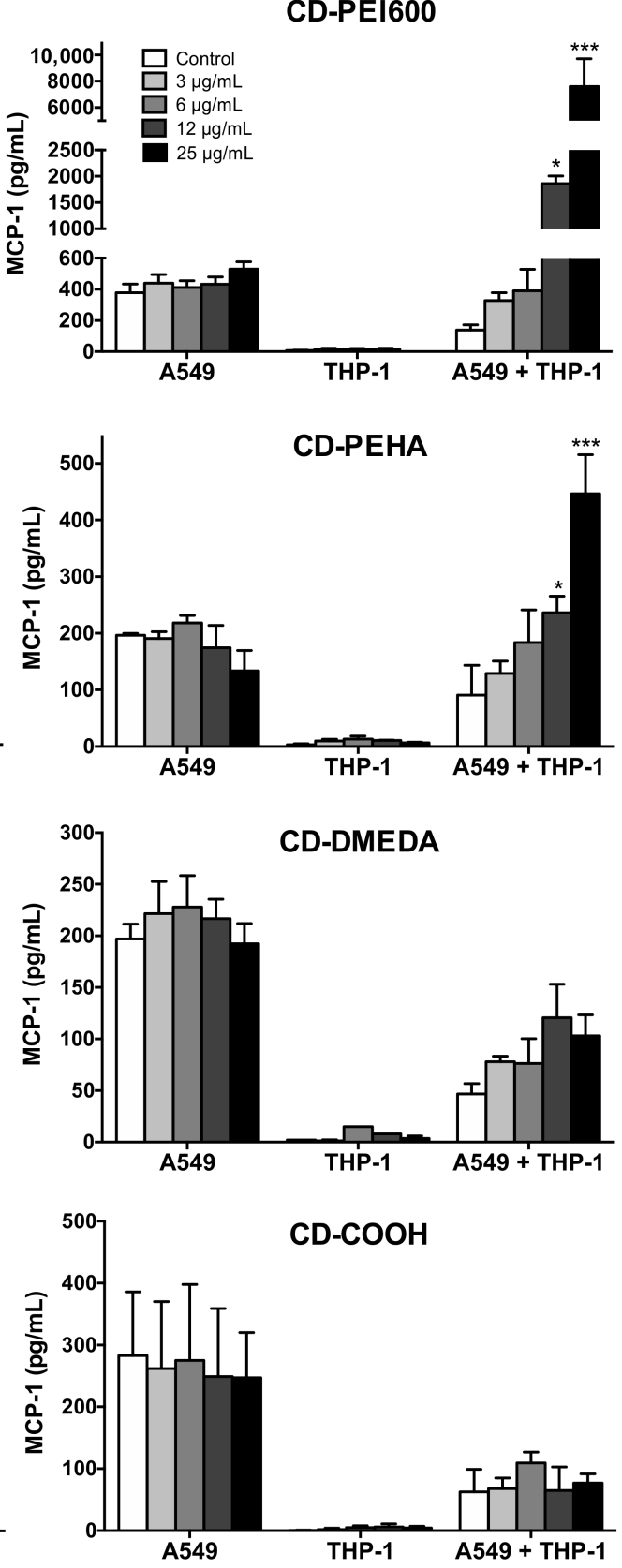

Figure 8. Inflammatory response evoked by CDs in mono- and co-cultures (A549:THP-1 seeding ratio of 2:1). Cultures were exposed to increasing concentrations (3-25 $\mu \mathrm{g} / \mathrm{mL}$ ) of CDs for $24 \mathrm{~h}$ and IL-8 (a) and MCP-1 (b) were quantified in cell culture supernatants. Data are means \pm SEM of $n=3$ experiments. Statistical differences at $p<0.05$ (one symbol), $p<0.01$ (two symbols) and $p<0.001$ (three symbols) were determined by ANOVA followed by the Tukey's test when compared to control unexposed cells (asterisks), to CD-exposed-THP-1 cells (hash), or to CD-exposed-A549 cells (dollar) in mono-cultures.

\section{Conclusions}

In this study, we developed a simple co-culture model associating epithelial cells and macrophages that mimics the lung alveolar region. Using carbon-based NPs of different surface charge properties and multiple biological endpoints, we established some added value for this co-culture model in comparison to the respective mono-cultures for NP toxicity testing, as summarized in Table 2. Regarding the cytotoxicity, NP uptake, and oxidative stress endpoints, we did not find any advantage of the co-culture model over 
mono-cultures, especially macrophages. In contrast, our data highlighted a substantial contribution of the co-culture regarding inflammation assessment since this model allowed us to measure an inflammatory response for all tested cationic NPs. In addition, based on coculture model data, we showed that the induced inflammatory response was hierarchically related to the surface charge density of cationic NPs. This underlines the major role of the surface charge properties in the toxicological responses of NPs, and the importance of considering the charge density, and not only the zeta potential, in the NP safety evaluation. To conclude, in our opinion, monitoring the inflammatory response in a co-culture model associating pulmonary epithelial cells and macrophages is the more powerful approach described thus far for discriminating as finely as possible the lung toxicological effects of NPs.

Table 2. Overview of the data.

\begin{tabular}{|c|c|c|c|c|c|c|c|}
\hline & & Viability loss & Necrosis & Uptake & ROS & IL-8 & MCP-1 \\
\hline \multirow[t]{4}{*}{ A549 } & CD-PEI600 & + & + & + & + & + & - \\
\hline & CD-PEHA & - & - & + & - & - & - \\
\hline & CD-DMEDA & - & - & + & - & - & - \\
\hline & CD-COOH & - & - & - & - & - & - \\
\hline \multirow[t]{4}{*}{ THP-1 } & CD-PEI600 & + & + & + & + & + & - \\
\hline & CD-PEHA & + & - & + & - & - & - \\
\hline & CD-DMEDA & - & - & - & - & - & - \\
\hline & $\mathrm{CD}-\mathrm{COOH}$ & - & - & - & - & - & - \\
\hline \multirow[t]{4}{*}{ A549+THP-1 } & CD-PEI600 & + & + & + & - & + & + \\
\hline & CD-PEHA & - & - & + & - & + & + \\
\hline & CD-DMEDA & - & - & + & - & + & - \\
\hline & CD-COOH & - & - & - & - & - & - \\
\hline
\end{tabular}

+: significant effect; -: no significant effect.

Author Contributions: Y.A. performed the experiments and analyzed the data. J.C. performed the experiments. M.R. performed the synthesis of CDs. L.L. supervised the study and revised the manuscript. F.P. supervised the study and revised the manuscript. C.R. analyzed the data, supervised the study and wrote the paper. All authors approved the final manuscript. All authors have read and agreed to the published version of the manuscript.

Funding: This research was supported by the Agence Nationale de la Recherche (ANR, ANR-18CE34-0005-01), by the Agence Nationale de Sécurite Sanitaire de l'Alimentation, de l'Environnement et du Travail (ANSES, EST-2015/1/005), and by the Interdisciplinary Thematic Institute 2021-2028 program of the University of Strasbourg, CNRS and Inserm (ANR-10-IDEX-0002 and ANR-20-SFRI0012) in the frame of the InnoVec Institute.

Institutional Review Board Statement: Not applicable.

Informed Consent Statement: Not applicable.

Data Availability Statement: Data presented in this study are available by requesting from the corresponding author.

Acknowledgments: The authors thank Pascal Didier for its help with CLSM (Laboratoire de Bioimagerie et Pathologies, UMR 7021, Faculté de Pharmacie, CNRS-Université de Strasbourg, Illkirch, France), as well as Claudine Ebel and Muriel Koch for their help with FACS experiments (Cytometry platform, IGBMC, Strasbourg).

Conflicts of Interest: The authors declare no conflict of interest. The funders had no role in the design of the study; in the collection, analyses, or interpretation of data; in the writing of the manuscript, or in the decision to publish the results. 


\section{References}

1. Nel, A.; Xia, T.; Madler, L.; Li, N. Toxic potential of materials at the nanolevel. Science 2006, 311, 622-627. [CrossRef]

2. Maynard, A.D. Nanotechnology: The next big thing, or much ado about nothing? Ann. Occup. Hyg. 2007, 51, 1-12.

3. Oberdorster, G.; Oberdorster, E.; Oberdorster, J. Nanotoxicology: An emerging discipline evolving from studies of ultrafine particles. Environ. Health Persp. 2005, 113, 823-839. [CrossRef] [PubMed]

4. Kreyling, W.G.; Semmler-Behnke, M.; Takenaka, S.; Moller, W. Differences in the biokinetics of inhaled nano- versus micrometersized particles. Acc. Chem. Res. 2013, 46, 714-722. [CrossRef]

5. Ronzani, C.; Spiegelhalter, C.; Vonesch, J.L.; Lebeau, L.; Pons, F. Lung deposition and toxicological responses evoked by multi-walled carbon nanotubes dispersed in a synthetic lung surfactant in the mouse. Arch. Toxicol. 2012, 86, 137-149. [CrossRef]

6. Muller, J.; Huaux, F.; Moreau, N.; Misson, P.; Heilier, J.F.; Delos, M.; Arras, M.; Fonseca, A.; Nagy, J.B.; Lison, D. Respiratory toxicity of multi-wall carbon nanotubes. Toxicol. Appl. Pharmacol. 2005, 207, 221-231. [CrossRef]

7. Elgrabli, D.; Floriani, M.; Abella-Gallart, S.; Meunier, L.; Gamez, C.; Delalain, P.; Rogerieux, F.; Boczkowski, J.; Lacroix, G. Biodistribution and clearance of instilled carbon nanotubes in rat lung. Part. Fibre Toxicol. 2008, 5, 20. [CrossRef]

8. Ribeiro, A.R.; Leite, P.E.; Falagan-Lotsch, P.; Benetti, F.; Micheletti, C.; Budtz, H.C.; Jacobsen, N.R.; Lisboa, P.N.; Rocha, L.A.; Kuhnel, D.; et al. Challenges on the toxicological predictions of engineered nanoparticles. Nanoimpact 2017, 8, 59-72. [CrossRef]

9. Klein, S.G.; Hennen, J.; Serchi, T.; Blomeke, B.; Gutleb, A.C. Potential of coculture in vitro models to study inflammatory and sensitizing effects of particles on the lung. Toxicol. In Vitro 2011, 25, 1516-1534. [CrossRef]

10. Drasler, B.; Sayre, P.; Steinhauser, K.G.; Petri-Fink, A.; Rothen-Rutishauser, B. In vitro approaches to assess the hazard of nanomaterials. Nanoimpact 2017, 8, 99-116. [CrossRef]

11. Hirsch, C.; Roesslein, M.; Krug, H.F.; Wick, P. Nanomaterial cell interactions: Are current in vitro tests reliable? Nanomedicine 2011, 6, 837-847. [CrossRef]

12. Bhowmick, R.; Gappa-Fahlenkamp, H. Cells and culture systems used to model the small airway epithelium. Lung 2016, 194, 419-428. [CrossRef]

13. Nel, A.; Xia, T.; Meng, H.; Wang, X.; Lin, S.J.; Ji, Z.X.; Zhang, H.Y. Nanomaterial toxicity testing in the 21st century: Use of a predictive toxicological approach and high-throughput screening. Acc. Chem. Res. 2013, 46, 607-621. [CrossRef]

14. Stone, V.; Johnston, H.; Schins, R.P.F. Development of in vitro systems for nanotoxicology: Methodological considerations. Crit. Rev. Toxicol. 2009, 39, 613-626. [CrossRef] [PubMed]

15. Hesler, M.; Aengenheister, L.; Ellinger, B.; Drexel, R.; Straskraba, S.; Jost, C.; Wagner, S.; Meier, F.; von Briesen, H.; Buchel, C.; et al. Multi-endpoint toxicological assessment of polystyrene nano- and microparticles in different biological models in vitro. Toxicol. In Vitro 2019, 61, e104610. [CrossRef]

16. Clift, M.J.; Gehr, P.; Rothen-Rutishauser, B. Nanotoxicology: A perspective and discussion of whether or not in vitro testing is a valid alternative. Arch. Toxicol. 2011, 85, 723-731. [CrossRef]

17. Frohlich, E. Comparison of conventional and advanced in vitro models in the toxicity testing of nanoparticles. Artif. Cell. Nanomed. Biotechnol. 2018, 46, 1091-1107. [CrossRef]

18. Fytianos, K.; Drasler, B.; Blank, F.; von Garnier, C.; Seydoux, E.; Rodriguez-Lorenzo, L.; Petri-Fink, A.; Rothen-Rutishauser, B. Current in vitro approaches to assess nanoparticle interactions with lung cells. Nanomedicine 2016, 11, 2457-2469. [CrossRef]

19. Alfaro-Moreno, E.; Nawrot, T.S.; Vanaudenaerde, B.M.; Hoylaerts, M.F.; Vanoirbeek, J.A.; Nemery, B.; Hoet, P.H. Co-cultures of multiple cell types mimic pulmonary cell communication in response to urban PM10. Eur. Respir. J. 2008, 32, $1184-1194$. [CrossRef]

20. Muller, L.; Riediker, M.; Wick, P.; Mohr, M.; Gehr, P.; Rothen-Rutishauser, B. Oxidative stress and inflammation response after nanoparticle exposure: Differences between human lung cell monocultures and an advanced three-dimensional model of the human epithelial airways. J. R. Soc. Interface 2010, 7, S27-S40. [CrossRef]

21. Dekali, S.; Divetain, A.; Kortulewski, T.; Vanbaelinghem, J.; Gamez, C.; Rogerieux, F.; Lacroix, G.; Rat, P. Cell cooperation and role of the P2X(7) receptor in pulmonary inflammation induced by nanoparticles. Nanotoxicology 2013, 7, 1302-1314. [CrossRef]

22. Napierska, D.; Thomassen, L.C.J.; Vanaudenaerde, B.; Luyts, K.; Lison, D.; Martens, J.A.; Nemery, B.; Hoet, P.H.M. Cytokine production by co-cultures exposed to monodisperse amorphous silica nanoparticles: The role of size and surface area. Toxicol. Lett. 2012, 211, 98-104. [CrossRef]

23. Riebeling, C.; Piret, J.P.; Trouiller, B.; Nelissen, I.; Saout, C.; Toussaint, O.; Haase, A. A guide to nanosafety testing: Considerations on cytotoxicity testing in different cell models. Nanoimpact 2018, 10, 1-10. [CrossRef]

24. Grabowski, N.; Hillaireau, H.; Vergnaud-Gauduchon, J.; Nicolas, V.; Tsapis, N.; Kerdine-Romer, S.; Fattal, E. Surface-modified biodegradable nanoparticles impact on cytotoxicity and inflammation response on a co-culture of lung epithelial cells and human-like macrophages. J. Biomed. Nanotechnol. 2016, 12, 135-146. [CrossRef] [PubMed]

25. Hino, M.; Kohchi, C.; Nishizawa, T.; Yoshida, A.; Nakata, K.; Inagawa, H.; Hori, H.; Makino, K.; Terada, H.; Sona, G.I. Innateimmune therapy for lung carcinoma based on tissue-macrophage activation with lipopolysaccharide. Anticancer Res. 2005, 25, 3747-3754. [PubMed]

26. Grotz, B.; Geppert, M.; Mills-Goodlet, R.; Hofer, S.; Hofstatter, N.; Asam, C.; Feinle, A.; Kocsis, K.; Berger, T.; Diwald, O.; et al. Biologic effects of nanoparticle-allergen conjugates: Time-resolved uptake using an in vitro lung epithelial co-culture model of A549 and THP-1 cells. Environ. Sci. Nano 2018, 5, 2184-2197. [CrossRef] 
27. Xu, X.Y.; Ray, R.; Gu, Y.L.; Ploehn, H.J.; Gearheart, L.; Raker, K.; Scrivens, W.A. Electrophoretic analysis and purification of fluorescent single-walled carbon nanotube fragments. J. Am. Chem. Soc. 2004, 126, 12736-12737. [CrossRef]

28. Himaja, A.L.; Karthik, P.S.; Singh, S.P. Carbon Dots: The newest member of the carbon nanomaterials family. Chem. Rec. 2015, 15, 595-615. [CrossRef]

29. Pierrat, P.; Wang, R.; Kereselidze, D.; Lux, M.; Didier, P.; Kichler, A.; Pons, F.; Lebeau, L. Efficient in vitro and in vivo pulmonary delivery of nucleic acid by carbon dot-based nanocarriers. Biomaterials 2015, 51, 290-302. [CrossRef]

30. Claudel, M.; Fan, J.H.; Rapp, M.; Pons, F.; Lebeau, L. Influence of carbonization conditions on luminescence and gene delivery properties of nitrogen-doped carbon dots. RSC Adv. 2019, 9, 3493-3502. [CrossRef]

31. Ghosal, K.; Ghosh, A. Carbon dots: The next generation platform for biomedical applications. Mat. Sci. Eng. C Mater. 2019, 96, 887-903. [CrossRef] [PubMed]

32. Du, J.J.; Xu, N.; Fan, J.L.; Sun, W.; Peng, X.J. Carbon dots for in vivo bioimaging and theranostics. Small 2019, 15 , e1805087. [CrossRef] [PubMed]

33. Mishra, V.; Patil, A.; Thakur, S.; Kesharwani, P. Carbon dots: Emerging theranostic nanoarchitectures. Drug Discov. Today 2018, 23, 1219-1232. [CrossRef] [PubMed]

34. Luyts, K.; Napierska, D.; Nemery, B.; Hoet, P.H.M. How physico-chemical characteristics of nanoparticles cause their toxicity: Complex and unresolved interrelations. Environ. Sci. Process. Impacts 2013, 15, 23-38. [CrossRef] [PubMed]

35. Braakhuis, H.M.; Park, M.V.D.Z.; Gosens, I.; De Jong, W.H.; Cassee, F.R. Physicochemical characteristics of nanomaterials that affect pulmonary inflammation. Part. Fibre Toxicol. 2014, 11, 18. [CrossRef]

36. Mailander, V.; Landfester, K. Interaction of nanoparticles with cells. Biomacromolecules 2009, 10, 2379-2400. [CrossRef]

37. Huhn, D.; Kantner, K.; Geidel, C.; Brandholt, S.; De Cock, I.; Soenen, S.J.H.; Gil, P.R.; Montenegro, J.M.; Braeckmans, K.; Mullen, K.; et al. Polymer-coated nanoparticles interacting with proteins and cells: Focusing on the sign of the net charge. ACS Nano 2013, 7, 3253-3263. [CrossRef]

38. Fan, J.H.; Claudel, M.; Ronzani, C.; Arezki, Y.; Lebeau, L.; Pons, F. Physicochemical characteristics that affect carbon dot safety: Lessons from a comprehensive study on a nanoparticle library. Int. J. Pharm. 2019, 569, e118521. [CrossRef]

39. Weiss, M.; Fan, J.H.; Claudel, M.; Sonntag, T.; Didier, P.; Ronzani, C.; Lebeau, L.; Pons, F. Density of surface charge is a more predictive factor of the toxicity of cationic carbon nanoparticles than zeta potential. J. Nanobiotechnol. 2021, 19, 5. [CrossRef]

40. Collot, M.; Kreder, R.; Tatarets, A.L.; Patsenker, L.D.; Mely, Y.; Klymchenko, A.S. Bright fluorogenic squaraines with tuned cell entry for selective imaging of plasma membrane vs. endoplasmic reticulum. Chem. Commun. 2015, 51, 17136-17139. [CrossRef]

41. Pinkerton, K.E.; Gehr, P.; Castaneda, A.; Crapo, J.D. Architecture and cellular composition of the air-blood barrier. In Comparative Biology of the Normal Lung, 2nd ed.; Elsevier Inc.: Amsterdam, The Netherlands, 2015; pp. 105-117.

42. Crapo, J.D.; Barry, B.E.; Gehr, P.; Bachofen, M.; Weibel, E.R. Cell number and cell characteristics of the normal human lung. Am. Rev. Respir. Dis. 1982, 126, 332-337.

43. Loret, T.; Peyret, E.; Dubreuil, M.; Aguerre-Chariol, O.; Bressot, C.; le Bihan, O.; Amodeo, T.; Trouiller, B.; Braun, A.; Egles, C.; et al. Air-liquid interface exposure to aerosols of poorly soluble nanomaterials induces different biological activation levels compared to exposure to suspensions. Part. Fibre Toxicol. 2016, 13, 58. [CrossRef]

44. Marriott, H.M.; Gascoyne, K.A.; Gowda, R.; Geary, I.; Nicklin, M.J.H.; Iannelli, F.; Pozzi, G.; Mitchell, T.J.; Whyte, M.K.B.; Sabroe, I.; et al. Interleukin- $1 \beta$ regulates CXCL8 release and influences disease outcome in response to Streptococcus pneumoniae, defining intercellular cooperation between pulmonary epithelial cells and macrophages. Infect. Immun. 2012, 80, 1140-1149. [CrossRef]

45. Jang, J.H.; Seo, J.Y.; Oh, J.; Kim, J.S.; Kim, E.J.; Kim, J.S. In vitro and in vivo anti-inflammatory activities of mixed fruit and vegetable juice. Food Sci. Biotechnol. 2016, 25, 905-909. [CrossRef] [PubMed]

46. Thomas, L.H.; Wickremasinghe, M.I.Y.; Sharland, M.; Friedland, J.S. Synergistic upregulation of interleukin-8 secretion from pulmonary epithelial cells by direct and monocyte-dependent effects of respiratory syncytial virus infection. J. Virol. 2000, 74, 8425-8433. [CrossRef] [PubMed]

47. Yang, D.; Cao, X.; Wang, F.; Jiang, H.; Feng, D.; Guo, H.; Du, L.; Jin, Y.; Chen, Y.; Yin, X.; et al. LFG-500, a novel synthetic flavonoid, suppresses epithelial-mesenchymal transition in human lung adenocarcinoma cells by inhibiting NLRP3 in inflammatory microenvironment. Cancer Lett. 2017, 400, 137-148. [CrossRef]

48. Morris, G.E.; Parker, L.C.; Ward, J.R.; Jones, E.C.; Whyte, M.K.B.; Brightling, C.E.; Bradding, P.; Dower, S.K.; Sabroe, I. Cooperative molecular and cellular networks regulate Toll-like receptor-dependent inflammatory responses. FASEB J. 2006, 20, $2153-2155$. [CrossRef]

49. Havrdova, M.; Hola, K.; Skopalik, J.; Tomankova, K.; Martin, P.A.; Cepe, K.; Polakova, K.; Tucek, J.; Bourlinos, A.B.; Zboril, R. Toxicity of carbon dots-Effect of surface functionalization on the cell viability, reactive oxygen species generation and cell cycle. Carbon 2016, 99, 238-248. [CrossRef]

50. Sima, M.; Vrbova, K.; Zavodna, T.; Honkova, K.; Chvojkova, I.; Ambroz, A.; Klema, J.; Rossnerova, A.; Polakova, K.; Malina, T.; et al. The differential effect of carbon dots on gene expression and DNA methylation of human embryonic lung fibroblasts as a function of surface charge and dose. Int. J. Mol. Sci. 2020, 21, 4763. [CrossRef] [PubMed]

51. Kletting, S.; Barthold, S.; Repnik, U.; Griffiths, G.; Loretz, B.; Schneider-Daum, N.; de Souza Carvalho-Wodarz, C.; Lehr, C.M. Co-culture of human alveolar epithelial (hAELVi) and macrophage (THP-1) cell lines. ALTEX 2018, 35, 211-222. [CrossRef] 
52. Wottrich, R.; Diabate, S.; Krug, H.F. Biological effects of ultrafine model particles in human macrophages and epithelial cells in mono- and co-culture. Int. J. Hyg. Environ. Health 2004, 207, 353-361. [CrossRef]

53. Stepanenko, A.A.; Dmitrenko, V.V. Pitfalls of the MTT assay: Direct and off-target effects of inhibitors can result in over/underestimation of cell viability. Gene 2015, 574, 193-203. [CrossRef]

54. Mohammadinejad, R.; Moosavi, M.A.; Tavakol, S.; Vardar, D.O.; Hosseini, A.; Rahmati, M.; Dini, L.; Hussain, S.; Mandegary, A.; Klionsky, D.J. Necrotic, apoptotic and autophagic cell fates triggered by nanoparticles. Autophagy 2019, 15, 4-33. [CrossRef] [PubMed]

55. Wei, X.; Shao, B.; He, Z.; Ye, T.; Luo, M.; Sang, Y.; Liang, X.; Wang, W.; Luo, S.; Yang, S.; et al. Cationic nanocarriers induce cell necrosis through impairment of $\mathrm{Na}(+) / \mathrm{K}(+)$-ATPase and cause subsequent inflammatory response. Cell Res. 2015, 25, 237-253. [CrossRef]

56. Ronzani, C.; Van Belle, C.; Didier, P.; Spiegelhalter, C.; Pierrat, P.; Lebeau, L.; Pons, F. Lysosome mediates toxicological effects of polyethyleneimine-based cationic carbon dots. J. Nanopart. Res. 2019, 21, 4. [CrossRef]

57. Marano, F.; Hussain, S.; Rodrigues-Lima, F.; Baeza-Squiban, A.; Boland, S. Nanoparticles: Molecular targets and cell signalling. Arch. Toxicol. 2011, 85, 733-741. [CrossRef] [PubMed]

58. Frohlich, E. The role of surface charge in cellular uptake and cytotoxicity of medical nanoparticles. Int. J. Nanomed. 2012, 7, 5577-5591. [CrossRef]

59. Mahmoudi, M.; Lynch, I.; Ejtehadi, M.R.; Monopoli, M.P.; Bombelli, F.B.; Laurent, S. Protein-nanoparticle interactions: Opportunities and challenges. Chem. Rev. 2011, 111, 5610-5637. [CrossRef] [PubMed]

60. Ritz, S.; Schottler, S.; Kotman, N.; Baier, G.; Musyanovych, A.; Kuharev, J.; Landfester, K.; Schild, H.; Jahn, O.; Tenzer, S.; et al. Protein corona of nanoparticles: Distinct proteins regulate the cellular uptake. Biomacromolecules 2015, 16, 1311-1321. [CrossRef] [PubMed]

61. Kuhn, D.A.; Vanhecke, D.; Michen, B.; Blank, F.; Gehr, P.; Petri-Fink, A.; Rothen-Rutishauser, B. Different endocytotic uptake mechanisms for nanoparticles in epithelial cells and macrophages. Beilstein J. Nanotechnol. 2014, 5, 1625-1636. [CrossRef] [PubMed]

62. Manke, A.; Wang, L.Y.; Rojanasakul, Y. Mechanisms of nanoparticle-induced oxidative stress and toxicity. Biomed. Res. Int. 2013, 2013, 942916. [CrossRef] [PubMed]

63. Wang, Y.F.; Adamcakova-Dodd, A.; Steines, B.R.; Jing, X.F.; Salem, A.K.; Thorne, P.S. Comparison of in vitro toxicity of aerosolized engineered nanomaterials using air-liquid interface mono-culture and co-culture models. Nanoimpact 2020, 18, 100215. [CrossRef]

64. Jantzen, K.; Roursgaard, M.; Desler, C.; Loft, S.; Rasmussen, L.J.; Moller, P. Oxidative damage to DNA by diesel exhaust particle exposure in co-cultures of human lung epithelial cells and macrophages. Mutagenesis 2012, 27, 693-701. [CrossRef]

65. Hufnagel, M.; Neuberger, R.; Wall, J.; Link, M.; Friesen, A.; Hartwig, A. Impact of differentiated macrophage-like cells on the transcriptional toxicity profile of $\mathrm{CuO}$ nanoparticles in co-cultured lung epithelial cells. Int. J. Mol. Sci. 2021, 22, 5044. [CrossRef] [PubMed]

66. Kose, O.; Tomatis, M.; Leclerc, L.; Belblidia, N.B.; Hochepied, J.F.; Turci, F.; Pourchez, J.; Forest, V. Impact of the physicochemical features of $\mathrm{TiO}_{2}$ nanoparticles on their in vitro toxicity. Chem. Res. Toxicol. 2020, 33, 2324-2337. [CrossRef] [PubMed]

67. Meindl, C.; Ohlinger, K.; Zrim, V.; Steinkogler, T.; Frohlich, E. Screening for effects of inhaled nanoparticles in cell culture models for prolonged exposure. Nanomaterials 2021, 11, 606. [CrossRef] 